\title{
Fine-grained pyroxenites from the Gansfontein kimberlite, South Africa: Evidence for megacryst magma - mantle interaction.
}

\author{
P. M. Doyle \\ Department of Geological Sciences, University of Cape Town, Rondebosch 7700. South Africa \\ P.O. Box 31316, Tokai 7966, South Africa \\ e-mail: geo-odyssey@ananzi.co.za. \\ D. R. Bell \\ Department of Geological Sciences, University of Cape Town, Rondebosch 7700, South Africa \\ Department of Geological Sciences and Department of Chemistry and Biochemistry, \\ Arizona State University, Tempe AZ 85287-1604, USA. \\ e-mail: David.R.Bell@asu.edu \\ A.P. le Roex \\ Department of Geological Sciences, University of Cape Town, Rondebosch 7700, South Africa \\ e-mail: aleroex@geology.uct.ac.za
}

2004 Geological Society of South Africa

\begin{abstract}
The Gansfontein kimberlite contains a suite of fine-grained xenoliths dominated by orthopyroxene, and containing ilmenite, phlogopite, and occasional garnet, with minor quantities of olivine and sulphide, Lamellar intergrowths of orthopyroxene and ilmenite were observed in one sample. The fine grained orthopyroxenite assemblages were observed as discrete xenoliths, as a vein in therzolite, and as a zoned margin surrounding a megacrystic dunite. The minerals are characterized by intra- and inter-grain chemical heterogeneity, but are on the whole compositionally similar to those in the abundant, highly evolved Cr-poor megacryst suite at Gansfontein. However, they differ to varying degrees from megacrysts in the concentration of minor elements such as $\mathrm{Cr}$. Al and Ti. Mineral compositions in a pyroxenite vein in therzolite are higher $\mathrm{Cr}$ and $\mathrm{Mg} \neq$, and lower in $\mathrm{Fe}^{3+}$ than in the discrete fine-grained pyroxenites, indicating chemical interaction with peridotite. A single zircon-bearing mica-clinopyroxenite has mineral compositions similar to MARID xenoliths.

Fine-grained orthopyroxenites, recognized previously from the Weltevreden and Mzongwana kimberlites and interpreted as rapidly crystallized magmas, are here suggested to result from a reaction between megacryst magma and solid mantle peridotite. Mica-clinopyroxenite may represent the liquid end-product of this reaction. Chemical and modal differences of orthopyroxenites from megacrysts result from reaction with peridotitic components, lack of buffering by typical megacryst mineral assemblages, and possibly shallower origins. Textures and fine-scale chemical disequilibrium indicate that reaction postdates some episodes of megacryst formation and was probably underway when the xenoliths were sampled by ascending kimberlite. Orthopyroxenegarnet thermobarometry indicates an origin of one Gansfontein pyroxenite at $\sim 1215^{\circ} \mathrm{C}$ and $\sim 3.3$ GPa, similar to the locus of megacryst crystallization under East Griqualand.

The Gansfontein pyroxenites indicate interaction of magmas at shallow levels within the subcontinental lithospheric mantle and provide evidence for melt-peridotite reaction that includes a possible reaction relationship between Tï-rich melt and olivine. Similar phase relations and processes may also play a role in megacryst petrogenesis, for which these pyroxenite xenoliths could represent a small-scale, initial stage analogue. The liquid end-products of such reation may be important components of kimberlites and mantle metasomatic fluids.
\end{abstract}

\section{Introduction}

The Gansfontein kimberlite, situated in the Karoo north of Beaufort West, South Africa, is one of the southern most kimberlites in South Africa, $\sim 170 \mathrm{~km}$ west of the inferred boundary of the Kaapvaal craton (Figure 1 ). Though a small and historically little-studied pipe (Rogers, 1910; Wagner, 1914; Rickwood, 1969), it contains abundant mantle-derived xenoliths. Most prominent is a suite of variably-deformed, Ferichmegacrysts of olivine, ilmenite and phlogopite, and unusually abundant, coarse-grained zircon (Doyle, 1999). The kimberlite also contains relatively abundant peridotite and occasional eclogite and pyroxenite xenoliths, as well as rare lower crustal mafic garnet granulites. Os isotope studies of peridotites gave Redepletion ages of $\sim 1.14$ to $\sim 1.2$ Ga, confirming the post Archean (i.e., "off-craton") age signature of the mantle in this region (Janney et al.. 1999; 2001). The peridotite xenoliths record evidence of a high temperature perturbation to a typical shield geotherm (Janney et al., 1999; Bell et al.. 2003).

Among the Gansfontein mantle xenoliths occur a number of samples with mineral compositions similar to those of the Cr-poor megacryst suite (Eggler et al., 1979: 


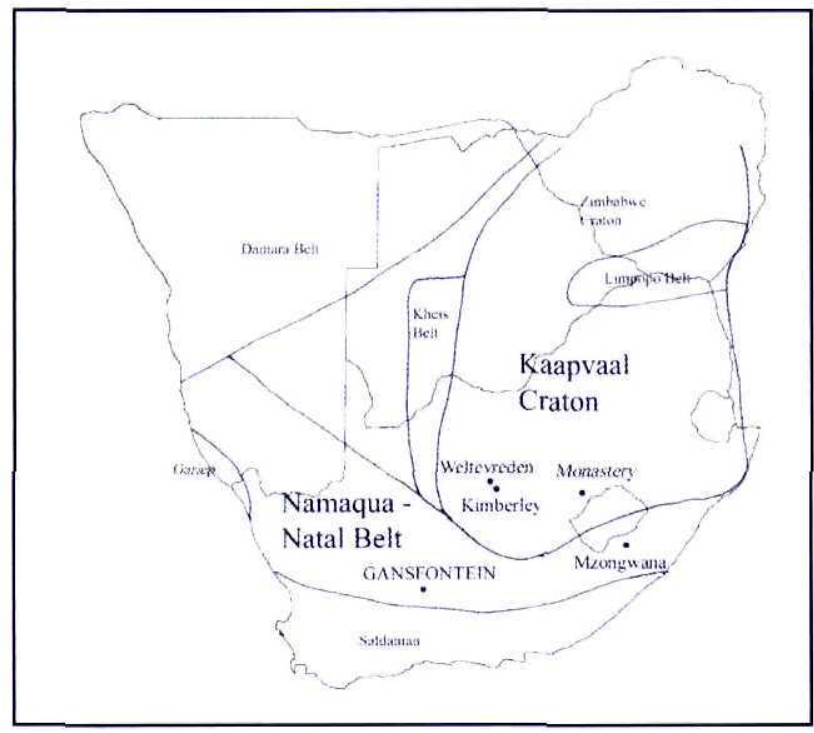

Figure 1. Location and tectonic setting of the Gansfontein kimberlite and the kimberlite sources of other xenoliths discussed in the text.

Gurney et al., 1979), but exhibiting unusual, fine-grained textures. The samples are ilmenite- and phlogopitebearing orthopyroxenites that are texturally and compositionally heterogeneous on the thin section scale. Similar samples were previously reported by Rawlinson and Dawson (1979) from the Weltevreden Mine (Barkly West area) and Boyd et al. (1984b) from Mzongwana in the East Griqualand kimberlite province (Figure 1). In both previous studies the samples were interpreted to result from rapid crystallization (quenching) of a magma related to the discrete nodule ( $\mathrm{Cr}$-poor megacryst) association.

Identifying the composition and origin of melts parental to the Cr-poor megacryst suite has been an important problem, because these inclusions are widely distributed in kimberlite xenolith suites and it has been suggested that they play an important role in mantle metasomatism and kimberlite petrogenesis (e.g. Gurney and Harte, 1980; Harte, 1983; Jones, 1987). There is increasing evidence that interaction between megacryst magmas and their mantle wall-rocks can be an important aspect of megacryst compositional evolution (Jones, 1987; Neal and Davidson, 1989; De Bruin, 1993; 2003; Bell and Moore, 2004). Previous studies have demonstrated the general importance of magma-mantle interaction in petrogenesis and compositional evolution of mantle-derived magmas, as well as in the modification of mantle lithologies and compositions (Kelemen et al., 1983; 1992; 1995; Kelemen, 1995; Wyllie et al., 1989; Wagner and Grove, 1998). There is also evidence that interaction with megacryst magmas has played a major role in the chemical evolution of the lower parts of the continental mantle lithosphere beneath southern Africa (Gurney and Harte, 1980; Burgess and Harte, 1999; Griffin et al., 2003).

In our interpretation, certain of the Gansfontein samples provide new evidence for the setting and nature
Table 1. Mineralogical composition of samples examined in this study.

\begin{tabular}{|c|c|}
\hline Sample No. & Minerals and modal percentages \\
\hline \multicolumn{2}{|c|}{ Discrete fine-grained pyroxenites } \\
\hline PMD99-048 & opx (45\%), phl (38\%), ilm (17\%), oliv (tr.) \\
\hline PMD99-056 & opx $(50 \%)$, ilm (30\%), phl (20\%), oliv (tr.) \\
\hline PMD99-098* & ilm $(\sim 15 \%)$, phl $(\sim 10 \%)$, gar $(\sim 75 \%)$ \\
\hline PMD99-099 & $\begin{array}{l}\text { opx }(55 \%) \text {, ilm }(25 \%) \text {, gar }(\sim 25 \%) \text {, phl }(15 \%) \text {, oliv } \\
\text { (tr), sulph (tr) }\end{array}$ \\
\hline
\end{tabular}

Additional samples consisting of opx, ilm, phl: PMD99-(025. PMD99-135. PMD99-153

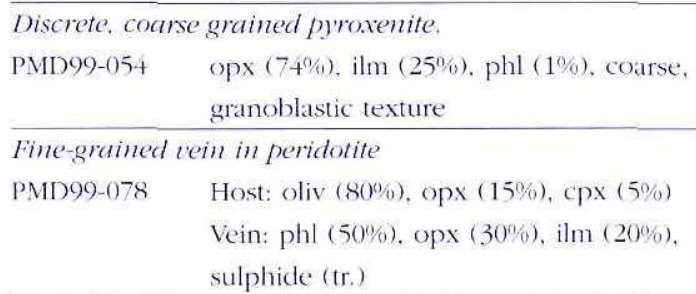

Fine-grained pyroxenitic assemblages associated with megacrysts. PMD99-057 Core: oliv (100\%).

Inner ("granoblastic") zone: opx ( $~ 88 \%)$, ilm (10\%), phl (2\%)Outer ("fasciculate") zone: opx, phl, ilm (modal zoning).

PMD99-022 Primary deformed megacryst: oliv (50\%), ilm $(50 \%)$

Fine-grained assemblage partially enclosed. in ilm: opx. phl, ilm.

Mica clinopyroxenite

PMD 99-030 cpx (50\%), phl $(45 \%)$,ilm (5\%), oliv (tr.), zircon (tr.)

Peridotite

PMD99-147 oliv, opx, sp, coarse granular texture PMD99-154 oliv, opx, coarse granular texture

* Sample PMDOy-098 strongly altered, primary modal proportions uncertain.

of such interaction. The utility of samples retaining evidence of mantle-magma interaction in the form of intra- and inter-grain chemical disequilibrium in constraining the nature and timing of mantle-magma interaction has been demonstrated previously (Smith and Boyd, 1987; Burgess and Harte, 1999; Griffin et al., 2001). We therefore present here a description of the petrographic and some chemical features of these fine grained pyroxenite xenoliths, comparing them with the Gansfontein megacryst suite, and with the Weltevreden and Mzongwana pyroxenites described by Rawlinson and Dawson (1979) and Boyd et al. (1984b). We also describe a single clinopyroxene-rich micaceous sample that has petrographic similarities to the "MARID" suite of micaceous xenoliths, compare its chemical composition to MARIDs elsewhere, and speculate on its mode of origin. Finally, we explore some possible implications of our observations for understanding petrogenesis of the Cr-poor megacryst suite and of kimberlite.

\section{Samples and analytical techniques}

Samples were collected in 1999 from spoil heaps of past 


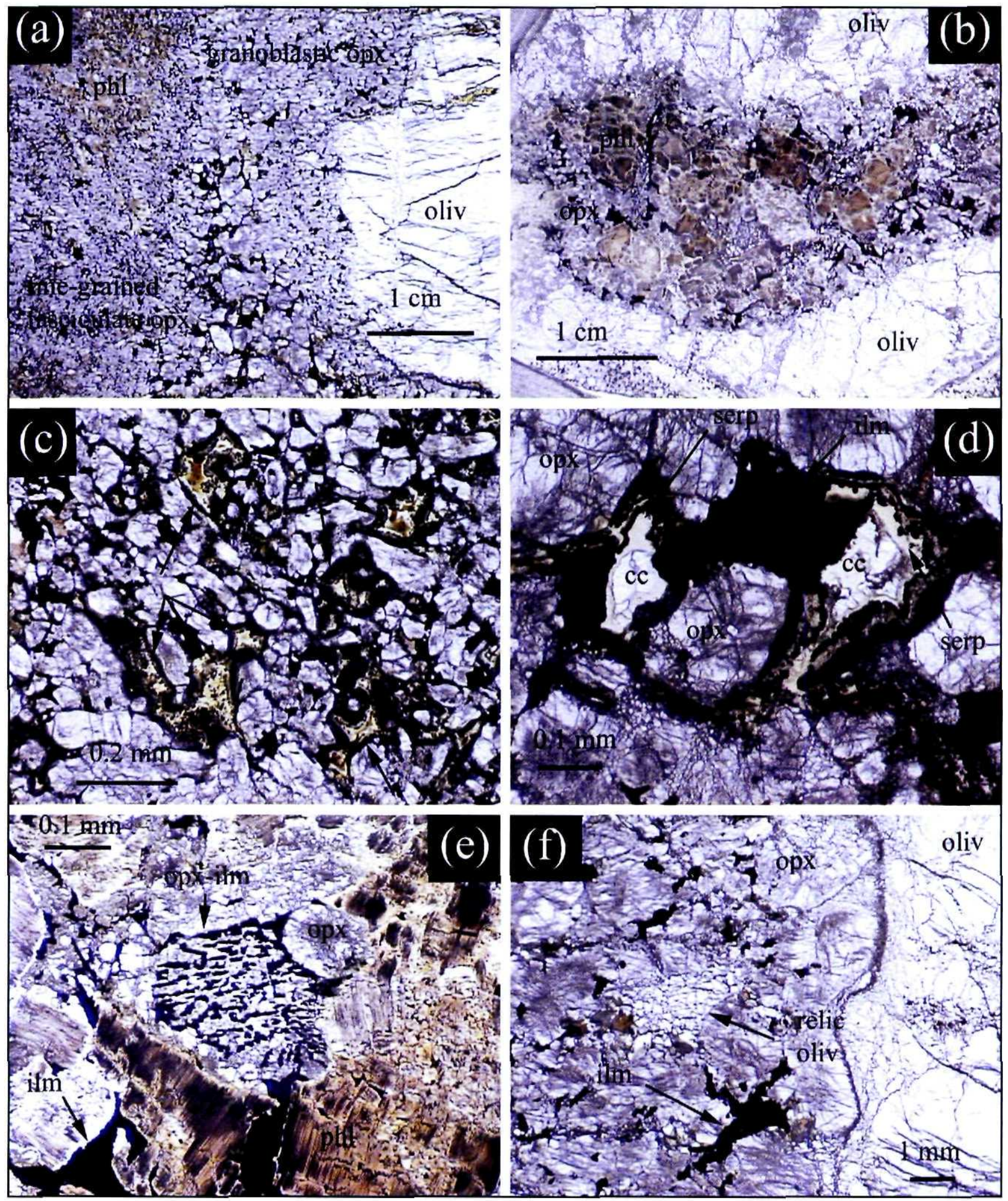

Figure 2. Petrographic features of Gansfontein hybrid nodules. (a) Low magnification view of PMD99-057, a coarse olivine suriounded by orthopyroxenes. The outer zone is mica-rich and contains sheaf like aggregates of fine-grained orthopyroxene. These two textures kimberlite, East Griqualand. (b) Low magnification view of sample PMD99-078, a fine grained vein comprising phlogopite, ilmenite and orthopyroxene. traversing a coarse therzolite. (c) Blocky-textured ("granoblastic") inner zone in sample PMD99-057 showing subrounded orthopyroxene $(\mathrm{opx})$ and irregular shaped ilmenite (ilm), with interstitial, irregularly shaped isotropic serpentine patches (serp) sometimes with calcite (cc) cores. (d) Magnified view of residual volatile-rich mineral patches between blocky orthopyroxene grains in matrix of fine grained pyroxenite PMD99-057. (e) Lamellar intergrowth of orthopyroxene (opx) and ilmenite (ilm) in the fine-grained vein of sample orthopyroxenite 
the

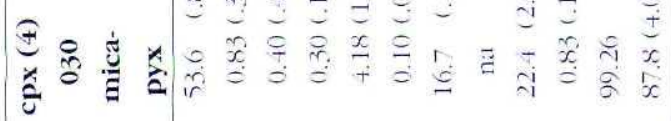

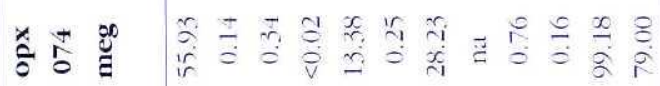

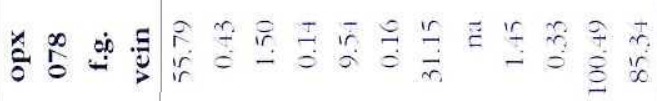

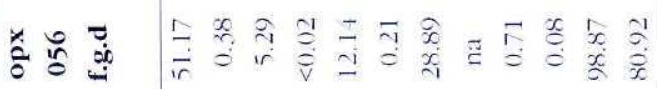

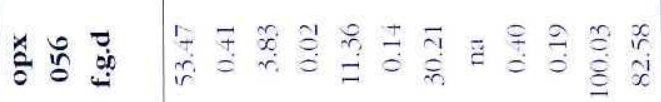

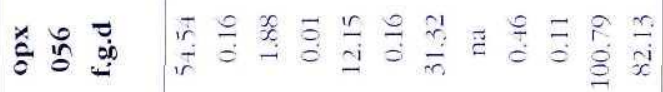

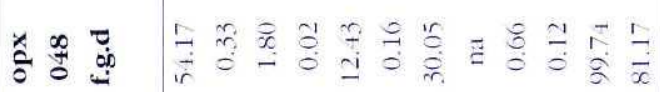

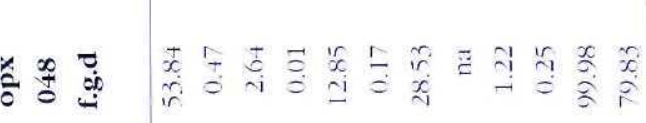

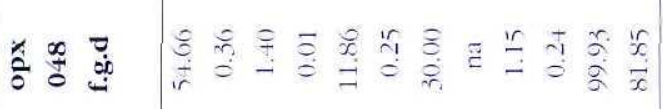

言

范

$\breve{\Xi}$

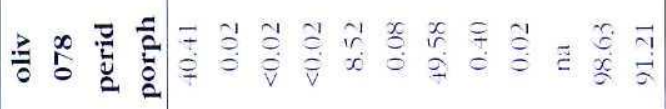

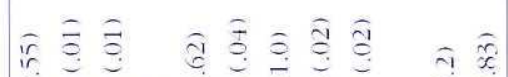
की

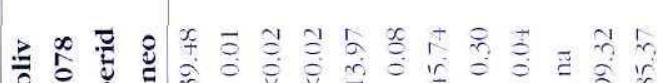

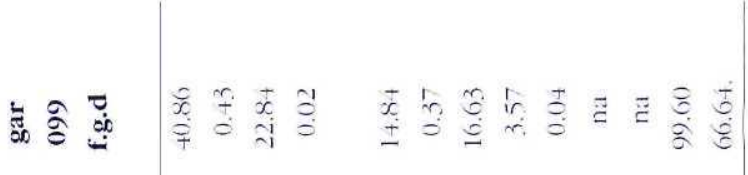

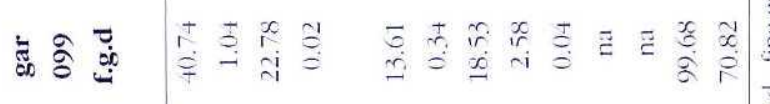

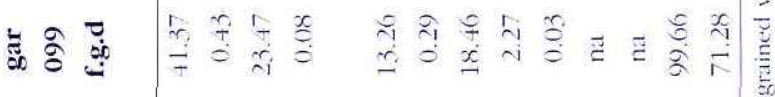

चี้

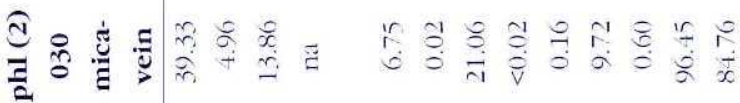

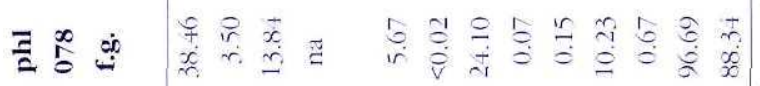

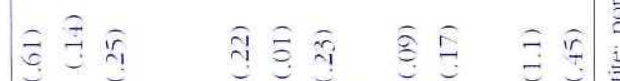

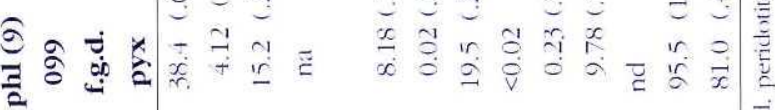

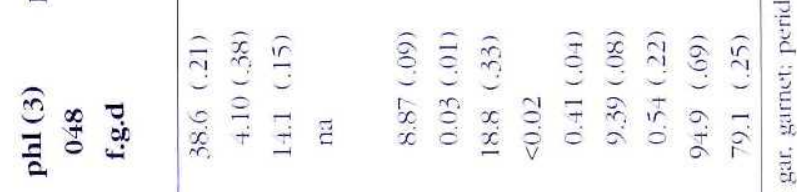

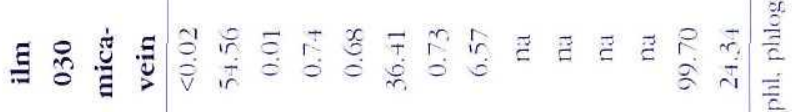

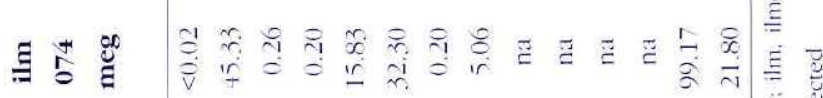

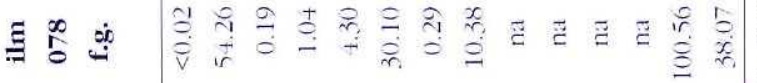

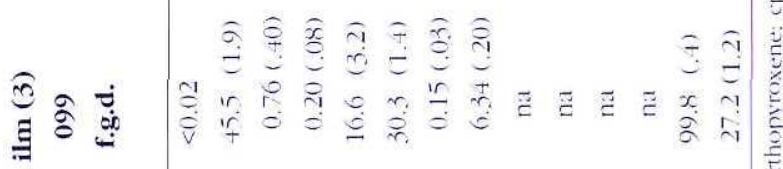

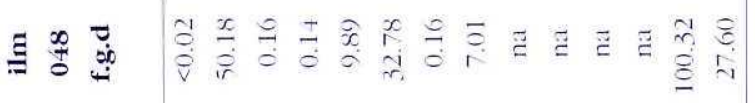

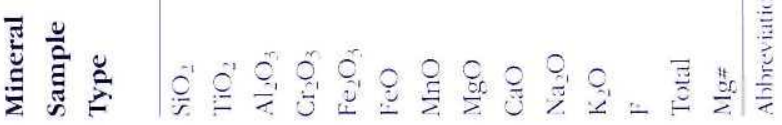


excavations on the kimberlite. The samples and their mineral assemblages are listed in Table 1. Major element analyses were determined on a subset of the samples using a Cameca Camebax electron microprobe at the Department of Geological Sciences, University of Cape Town. A $15 \mathrm{kV}$ accelerating potential was used, with a beam current of $40 \mathrm{nA}$. Count times for $\mathrm{CaO}, \mathrm{MnO}$ and $\mathrm{Cr}_{2} \mathrm{O}_{3}$ in garnet, and $\mathrm{NiO}$ and $\mathrm{CaO}$ in olivine were 30 seconds per element, while all other elemental oxides had peak count times of 10 seconds. The data were reduced with the PAP correction procedure (Pouchou and Pichoir, 1991). Representative electron microprobe analyses of the minerals are given in Table 2.

\section{Results \\ Petrography}

The suite examined in this study consists of eight discrete, fine-grained pyroxenites (i.e., composed of fine-grained pyroxenite alone), a coarse-grained orthopyroxenite, two composite samples consisting of coarse megacrysts with fine-grained domains similar to the fine-grained pyroxenites (Figure 2a), and one peridotite xenolith with a fine-grained pyroxenite vein (Figure 2b). A micaceous clinopyroxenite with visual similarity to the MARID suite of micaceous xenoliths was also examined. The samples described here are generally small $(<5 \mathrm{~cm})$, but larger samples of similar appearance were noted in the collection. Many samples have suffered partial alteration of the primary ferromagnesian silicates to secondary hydrous phases, commonly concentrated along fractures

\section{Fine-grained discrete xenoliths.}

These xenoliths occur both as rounded nodules and as angular rock fragments. The dominant mineral is orthopyroxene, with ubiquitous subordinate ilmenite and phlogopite. Garnet may be locally abundant and trace olivine is commonly present. Macroscopic heterogeneity in mineral distribution is common. Orthopyroxene exhibits a subrounded, equant and sometimes blocky habit (Figures $2 \mathrm{a}$ and 2c), with variable grain sizes $(0.2$ to $2.0 \mathrm{~mm})$, typically smaller than the minerals in peridotite xenoliths (commonly 2 to $10 \mathrm{~mm}$ ). Ilmenite occurs intergrown with, and interstitial to, the silicate phases, with rounded or lobate, amoeboid grains that may coalesce into irregular, vein-like structures (Figures 2e and 2f). It is normally evenly distributed throughout the rock, with occurrence of some coarse patches. The garnet-bearing sample PMD99-099 contains a megacryst-like segregation of polycrystalline ilmenite, $1 \mathrm{~cm}$ in diameter. Phlogopite occurs as dark-brown, fine-grained, randomly-oriented laths and patches $(0.2$ to $2 \mathrm{~mm})$ within polymineralic intergrowths, varying locally in abundance to define a crude layering. Garnet, occurring as highly fractured, turbid, brownish grains $(0.4$ to $3 \mathrm{~mm})$, was observed in two samples. Some of the garnets are poikilitic, containing inclusions of orthopyroxene. Sulphide was noted in sample PMD99-099, associated with ilmenite.
Lherzolite with phlogopite orthopyroxenite vein.

Sample PMD $99-078$, a therzolite, contains a thin $(\sim 1 \mathrm{~cm})$ vein (Figure $2 b$ ) that is similar in mineralogy and texture to the discrete pyroxenite xenoliths. This vein contains phlogopite, orthopyroxene and ilmenite, whereas the lherzolite matrix consists of a coarse-grained ( 4 to $5 \mathrm{~mm}$ ), protogranular assemblage of olivine $(\sim 80 \%)$, orthopyroxene $(\sim 15 \%)$ and clinopyroxene $(\sim 5 \%)$. Smaller, recrystallized olivine neoblasts are also found in the lherzolite matrix, mainly along grain boundaries and close to the vein. In contrast to the lherzolite matrix, the vein is very ilmenite- and phlogopite-rich, consisting of $\sim 50 \%$ phlogopite, $30 \%$ pyroxene, $20 \%$ ilmenite and trace quantities of calcite. Orthopyroxene sometimes forms lamellar intergrowths with ilmenite (Figures $2 \mathrm{~b}$ and $2 \mathrm{e}$ ) that are similar to the texture seen in pyroxene-ilmenite megacryst intergrowths (Boyd and Nixon, 1973; Gurney et al.. 1973). Similar graphic intergrowth of pyroxene and ilmenite in a fine-grained pyroxenite was reported by Rawlinson and Dawson (1979). Evenly dispersed sulphide of cubic habit is unusually abundant in this xenolith.

\section{Composite pyroxenite - megacryst sample.}

Sample PMD99-057 consists of an olivine core surrounded by a fine-grained pyroxenite selvage (Figure 2a). The core, $35 \mathrm{~mm}$ long and varying from $10-25 \mathrm{~mm}$ wide, may be a single deformed and partially recrystallised olivine crystal and is dominated by large, coarse areas with undulose extinction. Within this large crystal are smaller grains with a range of grain sizes, showing variable degrees of strain and suggesting that the olivine core was undergoing continuous deformation, annealing and recrystallization as it was sampled by the kimberlite. The olivine core is surrounded by inner and outer zones of fine-grained pyroxenite, with a texture similar to that found in the discrete fine-grained pyroxenite samples: PMD-99-056, PMD-99-048 and PMD-99-099. The inner zone (10 $1015 \mathrm{~mm}$ in thickness) is coarser-grained and relatively poor in phlogopite, containing larger orthopyroxenes (up to $2 \mathrm{~mm}$ ) with a sub-rounded, slightly blocky appearance. This texture, illustrated in Figures 2a, c and d, corresponds to that described as "granoblastic" by Boyd et al. (1984h). The finer-grained outer zone has higher phlogopite abundance, and contains orthopyroxene in sheaf-like patches (Figure 2a). Boyd et al. (1984h) termed this texture "fasciculate". The phlogopite has bent cleavages and is poikilitic, with abundant inclusions of small $(\sim 0.1 \mathrm{~mm})$ rounded to subhedral orthopyroxene grains. Irregularly shaped ilmenite is interspersed throughout the whole region, with a similar distribution of coarse and fine grain sizes. and appears interstitial to the orthopyroxene. Trace amounts of olivine are dispersed within the orthopyroxene-phlogopite-ilmenite matrix. One patch of olivine composed of recrystallised neoblasts is identical to material at the margin of the olivine core (Figure $2 \mathrm{f}$ ). The outer zone of this sample contains irregular 


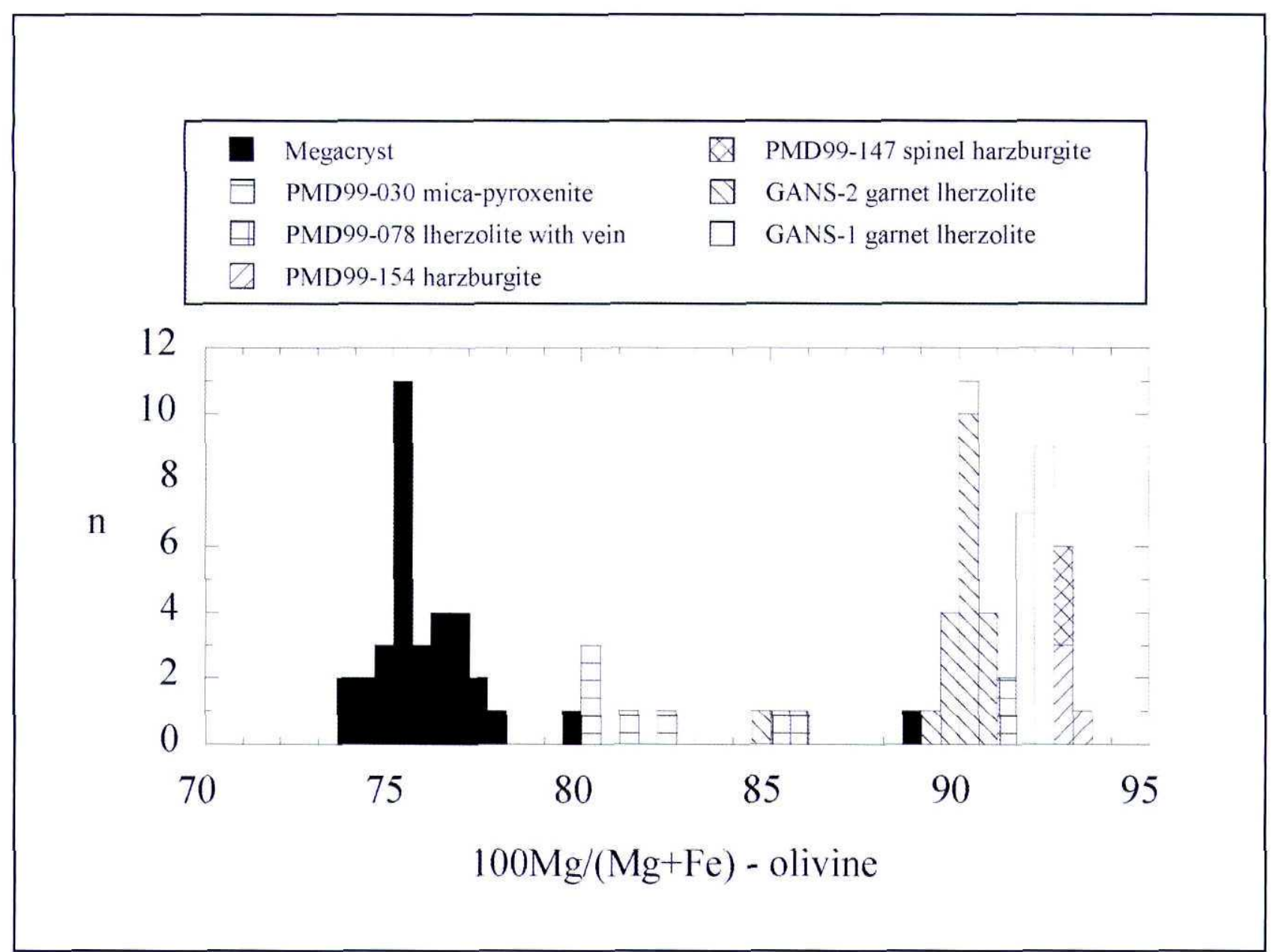

Figure 3. Histogram showing distribution of olivine compositions in Gansfontein xenoliths. Olivine megacryst data are from Doyle (1999) and each analysis represents a single sample. Olivine data for GANS1 and GA VS2 from P. Janney (unpublished) - see Janney et al. (1999: 2001). For the peridotite samples, multiple analyses are illustrated to demonstrate the compositional spread. Samples PMD99-078 and GANS2 have two compositions of olivine: Mg-rich coarse porphyroclasts and less abundant Fe-rich recrystallised olivine neoblasts.

isotropic patches of serpentine, of which a small proportion contain centers of calcite (Figures 2c and d). These are thought to represent crystallization products of a residual fluid.

In addition to the above sample that shows major components of both megacryst and pyroxenite types, two dominantly megacryst samples have small secondary features that are chemically similar to those of the pyroxenite suite. Sample PMD99-022 is an olivineilmenite intergrowth where the ilmenite contains an irregular inclusion $(\sim 3.5 \mathrm{~mm}$ diameter $)$ consisting of orthopyroxene, ilmenite and phlogopite, that is connected to the kimberlite matrix that encloses the xenolith. However, the mineralogy (in particular the presence of orthopyroxene and lack of fine grained spinels and perovskite) suggests that the inclusion did not result from kimberlite infiltration near the surface, and may represent an assemblage crystallized from an earlier trapped liquid. In contrast, sample PMD99-095 is a coarse orthopyroxene-ilmenite intergrowth with a secondary (host kimberlite related) phlogopiterich assemblage that includes small olivine grains (Fo88).

\section{Mica-clinopyroxenite xenolith}

Sample PMD99-030 is an intergrowth of randomly oriented, fine-grained phlogopite $(0.2$ to $2 \mathrm{~mm})$, clinopyroxene $(0.05$ to $0.3 \mathrm{~mm})$, ilmenite $(0.1$ to $0.5 \mathrm{~mm})$. and trace quantities of olivine $(0.05$ to $0.3 \mathrm{~mm})$ and zircon. Phlogopite grains poikilitically enclose ilmenite, and display undulose extinction. twinning, and chemical zoning indicated by colour changes. Ilmenite is evenly distributed throughout, and olivine occurs as highly fractured remnants.

\section{Ilmenite-orthopyroxenite}

PMD99-054 is dominantly orthopyroxene $(\sim 75 \%)$. It has a generally coarse $(0.2$ to $5 \mathrm{~mm})$, polycrystalline. granoblastic texture. The orthopyroxene contains fine exsolution lamellae of possible clinopyroxene that retain a constant orientation across grain boundaries, suggesting that the polycrystalline nature may in part be due to recrystallisation of a larger, strained crystal. Ilmenite (25\%) occurs throughout the pyroxenite as coarse (2 to $5 \mathrm{~mm}$ ) blebs with irregular margins, the smaller blebs appearing to be interstitial and irregularly elongate along the orthopyroxene grain boundaries. 
The ilmenite has a polycrystalline, mosaic texture with $120^{\circ}$ grain intersections. The ilmenite and pyroxene are not in direct contact and it appears that their mutual boundaries are a conduit to late-stage fluids that cause thin veins of hydrothermal alteration products along the interface. A single large $(6 \mathrm{~mm})$, strained, primary phlogopite grain is present.

\section{Mineral Chemistry}

\section{Olivine}

Forsterite (Fo) contents of peridotitic and megacryst olivines from Gansfontein are shown in Figure 3. The coarse peridotite olivines have a range in Fo contents from 90 to 93.5, with the higher values occurring in harzburgites. In most xenoliths the compositional heterogeneity is minor, however, two samples, GANS-2, a garnet therzolite studied by Janney et al. (1999) and PM1099-078, the lherzolite with a pyroxenitic vein, show evidence for more Fe-rich compositions (Fo $~ 85$ ) in the small recrystallized neoblasts. The mica-pyroxenite sample PMD99-030 also contains Fe-rich olivine (Fo 80 to 82), with a higher $\mathrm{CaO}$ content than the megacrysts, ranging from 0.06 to 0.10 weight \%. The megacryst olivines are the most Fe-rich (Fo 73-78): one outlying "megacryst" olivine with Fo 88 is actually a fine-grained secondary reaction product formed in a fracture due to kimberlite reaction (see description of PMD99-095 above).

\section{Ilmenite}

Ilmenites from the pyroxenite suite xenoliths are compositionally heterogeneous (Table 2), with the greatest degree of heterogeneity found in the vein sample PMD99-078. The pyroxenite suite ilmenites overlap the megacryst suite ilmenites with respect to the $\mathrm{Mg} / \mathrm{Fe}$ ratio (Figures 4 and 5 ), but have a range of $\mathrm{Fe}^{3+}$ contents that extend to very low hematite contents ( $\mathrm{Hm}<5 \%$, Figure 4). Those from the two discrete pyroxenite xenoliths PMD99-048 and PMD99-099 are closest to the compositions of the megacrysts and most analyses are indistinguishable from them. The micapyroxenite PMD99-(030 and vein sample PMD99-078 are low in $\mathrm{Fe}^{3+}$, with high and variable $\mathrm{Cr}_{2} \mathrm{O}_{3}$ (Figure 5). Ilmenite in the vein sample is also more magnesian. The Gansfontein ilmenites are, with exception of a few anomalous megacrysts, all more Fe-rich than the Mzongwana pyroxenites (Boyd et al., 1984b).

\section{Phlogopite}

The phlogopite in the discrete pyroxenites has higher $\mathrm{TiO}_{2}$ and $\mathrm{Al}_{2} \mathrm{O}_{3}$ contents and lower $\mathrm{Mg} *$ $[=100 \mathrm{Mg} /(\mathrm{Mg}+\mathrm{Fe})]$ than the single Gansfontein megacryst phlogopite analyzed (Table 2, Figure 6). $\mathrm{Al}$ and $\mathrm{Ti}$ contents of the phlogopite occurring in the pyroxenite vein in therzolite (PMD99-078) and in the mica clinopyroxenite sample PMD99-030 are similar to those in the discrete pyroxenite samples, but the $\mathrm{Mg} \#$ is higher. The $\mathrm{Al}_{2} \mathrm{O}_{3}$ content ranges from 13.0 to 15.8 weight $\%$, while the $\mathrm{TiO}_{2}$ ranges from 3.5 to 5.0

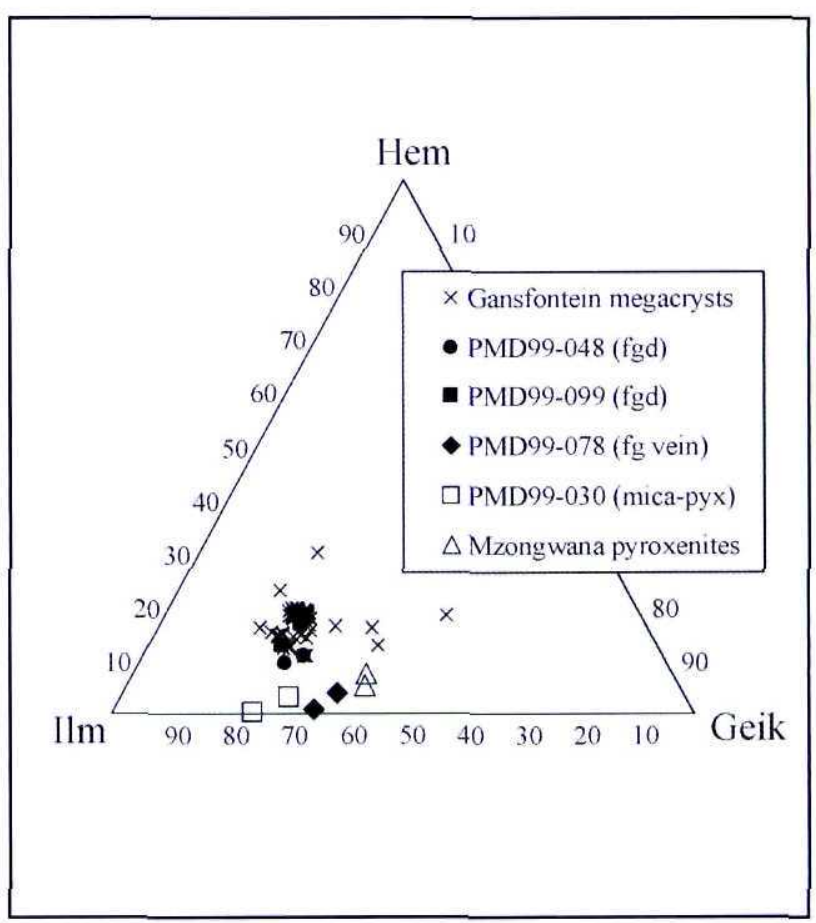

Figure 4. Hmenite compositions plotted in the HematiteGeikielite-Ilmenite ternary diagram. Individual Gansfontein ilmenite megacryst analyses from Doyle (1999) and Bell, unpublished data. Mzongwana pyroxenite data from Boyd et al. $(1984$ b) $. \mathrm{Fgd}=$ fine-grained discrete pyroxenites, mica-pyx $=$ mica clinopyroxenite. The fine-grained discrete xenoliths overlap the megacryst compositions substantially. With other samples containing less $\mathrm{Fe}^{3+}$.

weight $\%$, which is higher than observed for most other mantle-derived micas. A late generation of mica grown within a fracture in a megacryst (PMD99-095) has a composition similar to that of the pyroxenite suite mica. The Mzongwana pyroxenites have high $\mathrm{TiO}_{2}$ contents that range to even greater values (up to 6.8 weight \%: Boyd et al., 1984b)

\section{Orthopyroxene}

The orthopyroxene grains within the discrete pyroxenite suite xenoliths are heterogeneous with respect to $\mathrm{Al}_{2} \mathrm{O}_{3}$ (1.8 to 5.3 weight os in garnet-bearing sample PMD99099 alone), $\mathrm{Ca}=[=100 \mathrm{Ca} /(\mathrm{Ca}+\mathrm{Mg})](0.9$ to 3.0$)$ and $\mathrm{TiO}_{2}$ (0.15 to 0.47 weight \%) (Table 2; Figure 7). Al and Ti contents are well above those seen in the megacryst orthopyroxenes, whereas $\mathrm{Mg} *$, ranging from 79.0 to 82.7, overlaps that of megacryst orthopyroxenes. The vein orthopyroxenes are also compositionally heterogeneous and define a trend of increasing $\mathrm{Al}_{2} \mathrm{O}_{3}$ with decreasing $\mathrm{Mg} \#$. These orthopyroxenes have higher $\mathrm{Cr}_{2} \mathrm{O}_{3}(0.08$ to 0.14 weight \%) and $\mathrm{CaO}(0.77$ to 1.69 weight (\%) contents. In general, it appears that orthopyroxene in pyroxenite xenoliths records compositional disequilibrium on a fine scale, including zoning of $\mathrm{Al}_{2} \mathrm{O}_{3}$ and $\mathrm{Mg} \#$ within grains. The compositions appear to overlap the megacrysts in certain elements, but depart from them in broad arrays 


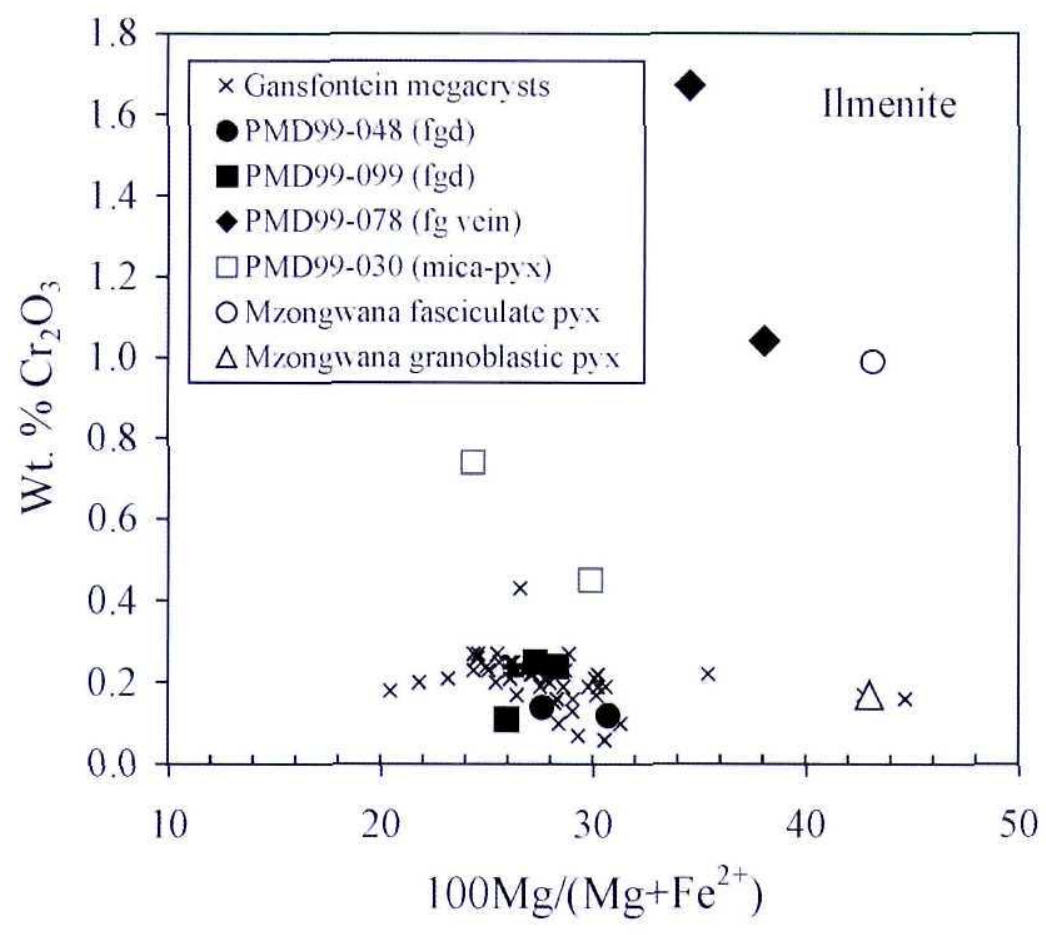

Figure 5. Ilmenite $\mathrm{Cr}_{2} \mathrm{O}_{3} \mathrm{vs} . \mathrm{Mg}^{7}$. Data sources and abbreviations as for Figure 4.

in Figures $7 \mathrm{a}$ and $7 \mathrm{~b}$. Orthopyroxenes in the pyroxenites from Mzongwana are similarly heterogeneous (Figure 7).

\section{Garnet}

Two pyroxenite suite xenoliths contain garnet and only those from PMD99-099 were analyzed. Substantial heterogeneity was encountered in $\mathrm{CaO}, \mathrm{Na}_{2} \mathrm{O}$ and $\mathrm{TiO}_{2}$ contents and $\mathrm{Mg} \#$ (Figure 8). Grains are individually zoned ( $\mathrm{Mg} \# 67$ to 72 in the most extreme case), with both symmetrical and asymmetrical zoning being observed. Similar compositional heterogeneity is evident in the Mzongwana and Weltevreden pyroxenites. A negative correlation between $\mathrm{Mg} *$ and $\mathrm{CaO}$ content of the garnets (Figure 8c) is unusual for mantle-derived garnets, particularly of the megacryst suite, which commonly have constant $\mathrm{CaO}$ contents. The $\mathrm{CaO}$ contents range from 2.2 to 3.5 weight $\%$, which is lower than megacryst garnets in general and lower than observed for the Mzongwana pyroxenites, but very similar to the Weltevreden sample. However, the $\mathrm{Mg} \neq$ versus $\mathrm{CaO}$ trend projects towards compositions of the most Fe-rich Monastery megacrysts (Figure $8 \mathrm{c}$ ) that are known to coexist with ilmenite (Gurney et al., 1979) and in the case of $\mathrm{TiO}_{2}$ (Figure 8a), substantial overlap with the Fe-rich Monastery compositions is attained. For $\mathrm{Cr}_{2} \mathrm{O}_{3}-\mathrm{Mg} \neq$ relationships, this overlap is essentially complete (Figure 8b).

\section{Clinopyroxene}

Sample PMD-99-030 contains diopside with a wide range of $\mathrm{Mg} \#$ from 82.6 to 92.5, and very high Ti content (0.6 to 1.2 weight $\% \mathrm{TiO}_{2}$ ), similar to fasciculate pyroxenite from Mzongwana (Figure 9a). However, in marked contrast to Cr-poor megacryst pyroxenes and the Mzongwana pyroxenites, it has a low $\mathrm{Al}$ content $\left(<0.05\right.$ to 1.2 weight $\left.\% \mathrm{Al}_{2} \mathrm{O}_{3}\right)$ that is similar to diopside in MARID xenoliths (Dawson and Smith, 1977) and Granny Smith pyroxenes (Boyd et al., 1984a) (Figures 9b and c). The range in $\mathrm{Ca} \#$ from 45.9 to 50.6 is also similar to these groups of xenoliths (Figure 9c). The micaceous pyroxenite diopsides have low $\mathrm{Cr}$ contents $(0.1$ to 0.5 weight $\% \mathrm{Cr}_{2} \mathrm{O}_{3}$ ).

\section{Geothermobarometry}

Few opportunities for quantitative thermobarometry of the Gansfontein pyroxenite suite xenoliths exist because of the lack of clinopyroxenc and the presence of garnet in only one sample. The coexistence of garnet and orthopyroxene allows application of the thermobarometry based on $\mathrm{Fe}-\mathrm{Mg}$ - $\mathrm{Al}$ exchange between these two minerals. However, the large degree of chemical disequilibrium observed in this sample requires a careful application of the methods. With close attention to petrographic context, we selected a closely located pair of garnet and orthopyroxene analyses as 


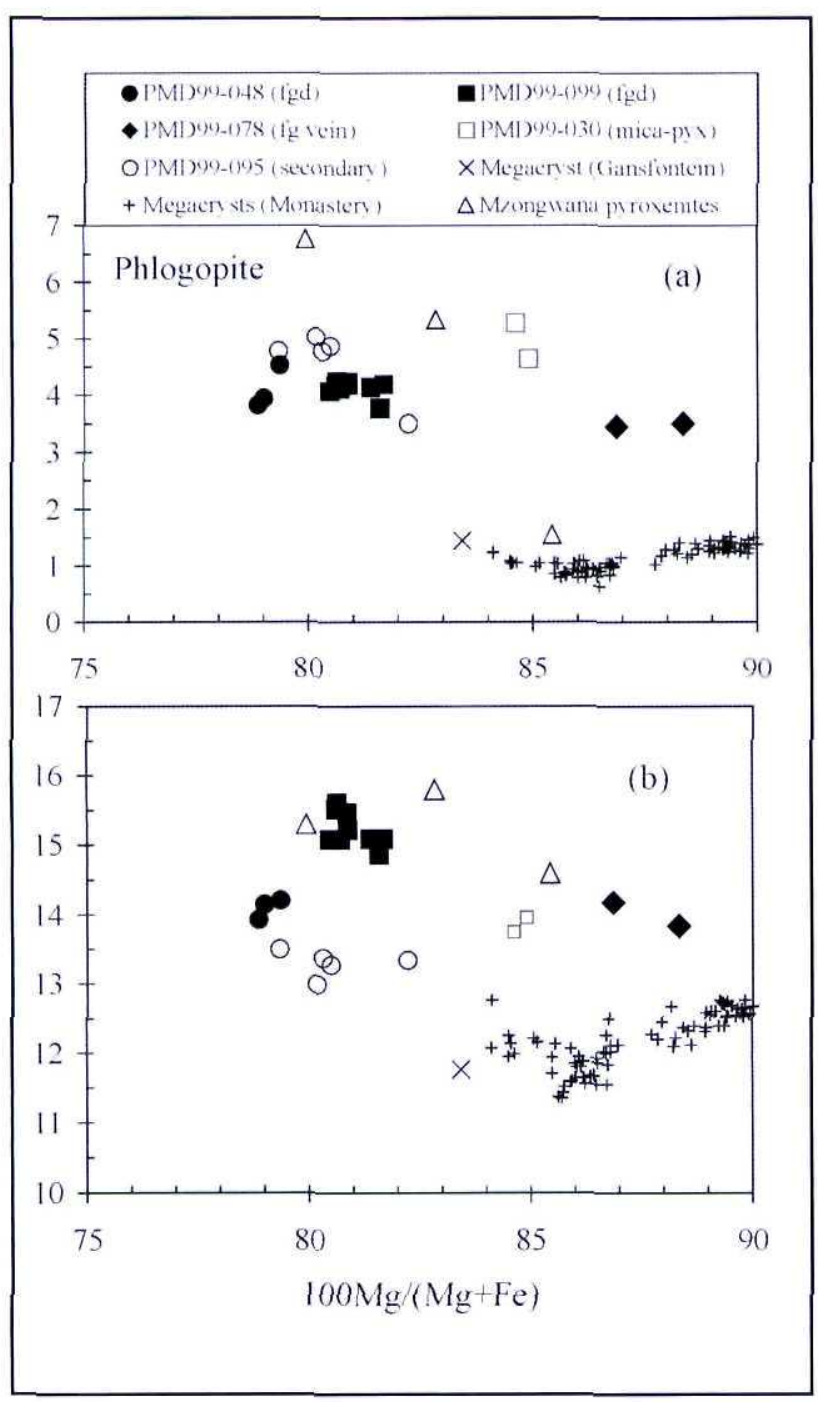

Figure 6. Phlogopite compositions: (a) $\mathrm{TiO}_{2} \mathrm{vs} . \mathrm{Mg} \#$ and (b) $\mathrm{Al}_{2} \mathrm{O}_{3}$ vs. Mg*. The Gansfontein megacryst composition is the mean of fifteen analyses of sample PMD99-(032 (Doyle, 1999). PMD99-095 phlogopite is dark red-brown mica occurring as secondary replacement of megacryst phlogopite along irregular fractures. Monastery megacryst data from Moore (1986). Mzongwana pyroxenite data from Boyd of al. (1984h) and include light and dark brown phlogopite from a micat-rich xenolith ( 4522 2B C) and mica from a fasciculate pyroxenite (3087A). Abbreviations as for Figure 4 .

those most likely to yield the most accurate P-T estimates. These were of a small orthopyroxene inclusion, enclosed near the core of a poikilitic garnet of sample PMD99-099, and the adjacent garnet. Pressure and temperatures were calculated with the program TP97 (Smith, 1999) from the garnet and orthopyroxene compositions, using the $\mathrm{T}_{\mathrm{H} \text { ar }}$ and $\mathrm{P}_{\mathrm{BK}} \mathrm{x}$ methods (Harley, 1984; Brey and Köhler, 1990). All Fe in garnet and pyroxene was treated as ferrous in these calculations. This mineral pair produced a temperature estimate of $1215^{\circ} \mathrm{C}$ at $3.30 \mathrm{GPa}$. The use of garnet rim compositions with the compositional data for this particular orthopyroxene inclusion provide a marginally lower set of P-T conditions at $\sim 1190^{\circ} \mathrm{C}$ and $\sim 3.2 \mathrm{GPa}$. This P-T

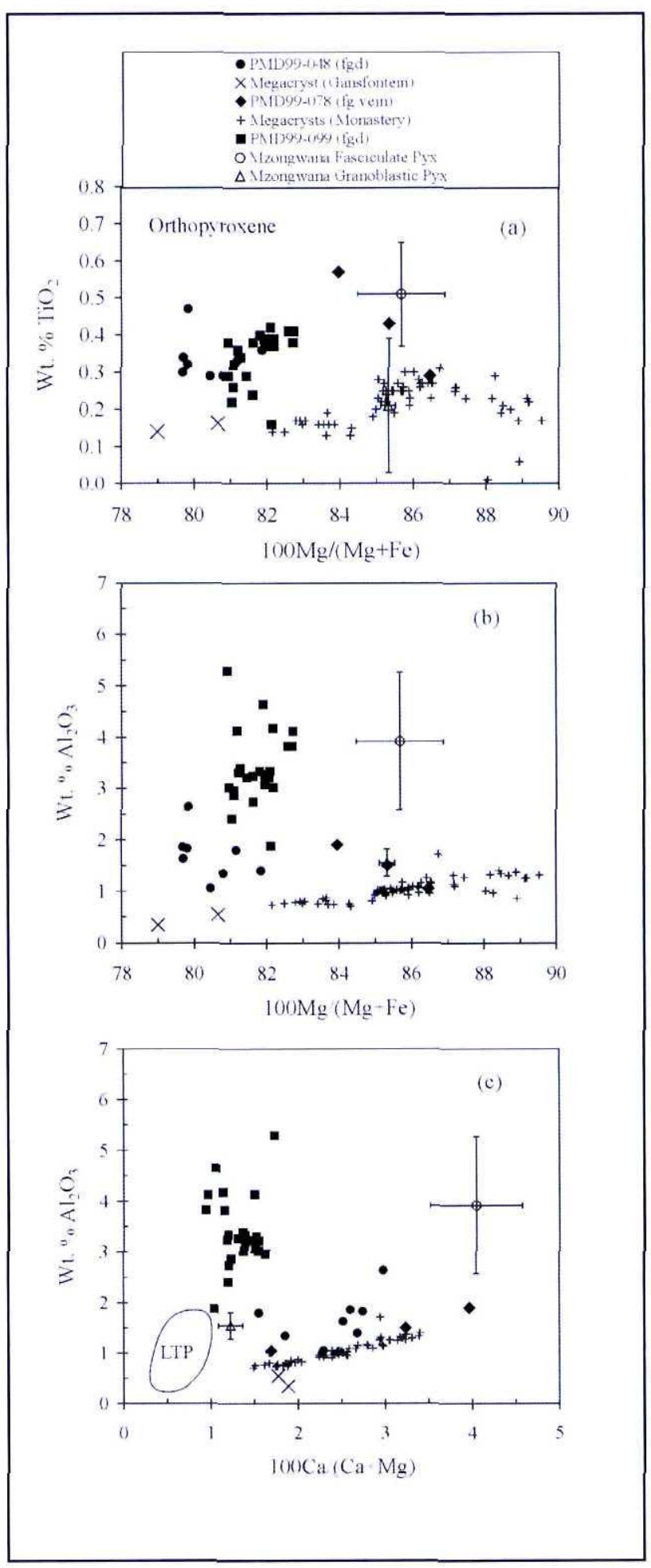

Figure 7. Orthopyroxene compositions, (a) $\mathrm{TiO}_{2}$ is $\mathrm{Mg}$, (b) $\mathrm{Al}_{2} \mathrm{O}_{3}$ vis. $\mathrm{Mg}=$. (c) $\mathrm{Al}_{2} \mathrm{O}_{3}$ is, $\mathrm{Ca}=$. 1) ata for Gansfontein pyroxenites are multiple individual analyses of different grains and areas of grains. illustrating compositional feterogeneity. Mzongwana pyroxenite data from Boyd et al. (1984b), including standard deviations of multiple analyses reported in that study. Monastery megacryst data from Jakob (1977), Gurncy et al. (1979) and Moore (1986). I.TP is the field of orthopyroxenes from lowtemperature peridotites from Hebron (Robey, 1981) and assorted Lesotho kimberlites, and are thought to be representative of lowtemperature lithospheric mantle peridotite orthopyroxene compositions in general. Other abbreviations as for Figure 4. 


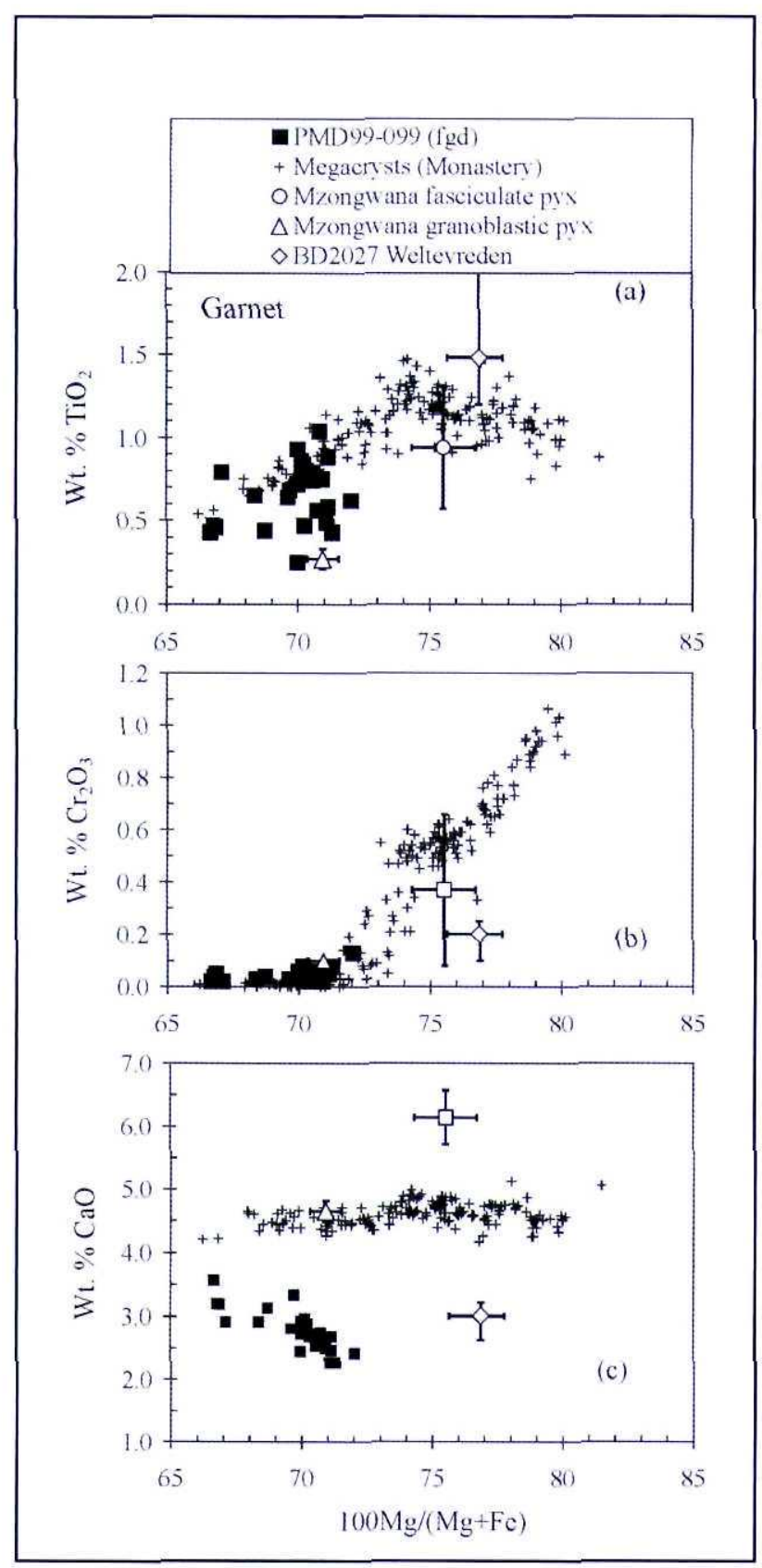

Figure 8. Garnet compositions. (a) $\mathrm{TiO}_{2}$ vs. $\mathrm{Mg}_{\mathrm{g}}$. (b) $\mathrm{Cr}_{2} \mathrm{O}_{4}$ is. $\mathrm{Mg}=$ and (c) $\mathrm{CaO}$ vs. Mg*. Abbreviations and data sources as for Figure 7

point is plotted in Figure 10, along with pressure and temperatures of peridotites from Lesotho, East Griqualand and the nearby Hebron kimberlite that we have calculated from published data using the same $\left(\mathrm{T}_{\mathrm{H}: \mathrm{a}}-\mathrm{P}_{\mathrm{BKV}}\right)$ thermobarometric methods. The preferred $\mathrm{P}$ $\mathrm{T}$ estimate represents significant deviation to high temperature from a steady state shield geotherm at this depth (Pollack and Chapman, 1977), in agreement with various other features indicating magmatic infiltration. The temperature of $1215^{\circ} \mathrm{C}$ is within the range of typical megacryst magma temperatures (Nixon and Boyd, 1973; Gurney et al., 1979): Schulze, 1987), towards the lower range expected of the more evolved compositions.

The depth of $\sim 110 \mathrm{~km}$ indicated by this pressure is substantially shallower than estimates for the crystallization depths of most cratonic megacryst suites or the Fe-Ti rich sheared peridotite xenoliths with which they are thought to be associated (e.g.. Boyd and Nixon, 1975; Hops et al., 1989). However, it overlaps with the lower end of the range of pressures calculated by the same methods for the high temperature peridotites from the East Griqualand off-craton kimberlites.

\section{Discussion}

\section{Summary and significance of petrographic observations}

The chemically-defined "megacryst" suite at Gansfontein contains both coarse and fine grained samples that exhibit a range of deformation textures (Doyle, 1999), whereas the pyroxenite suite is distinguished by the intergrowth of minerals on a fine $(<1 \mathrm{~mm}$ to $5 \mathrm{~mm})$ scale. Thus, the fine grain size does not simply represent the recrystallisation of large homogeneous domains. The sheaf like. fasciculate pyroxenes, blocky, granoblastic pyroxenes, and finely intergrown, lobate ilmenite are also characteristic textures not seen in the megacryst suite.

Rawlinson and Dawson (1979) and Boyd et al. (198+b) ascribed similar fasciculate textures to rapid crystallization, amounting to quenching of a magma, possibly in thin dikes or by inclusion of pyroxenite magma in kimberlite. Textures resembling those in the natural rocks, including silicate-ilmenite intergrowths, were produced by melting and rapidly crystallizing samples of the Weltevreden sample B1)2027 in the laboratory (Rawlinson and Dawson, 1979). The vein-like feature in the lherzolite (PMD99-078) supports a magmatic origin for these xenoliths. However, both sample BD2027 and PMD99-099 contain later coarsegrained ilmenite, indicating that interpretations other than quenching, that involve longer time scales must be permissible, because residence in the mantle has not destroyed the fine-grained "quench-like" textures. As discussed later, the composition of the fine-grained pyroxenite is also inconsistent with known magmatic liquids. For these reasons, we consider an alternative to the magmatic quenching hypothesis.

The zoned pyroxenitic margin to the coarse-grained, deformed dunite/olivine megacryst suggests that these textures could also arise from reaction between magma and solid mantle. The textures of the fine grained pyroxenite zones around the coarse olivine sample PMD 99-057 look very similar to the textures of the discrete pyroxenite samples PMD99-048, -056 and -099 and to similar discrete samples from the Mzongwana kimberlite reported by Boyd et al. (1984b). The banded or layered character of some xenoliths could plausibly be caused by either igneous or metasomatic processes involving the migration of reaction fronts. The textural symmetry about the inclusion (PMD99-057) and the coarse-grained vein (BD2027) suggests that such fronts are related to the proximity of solid mantle.

The relative abundance of minerals in the finegrained pyroxenite suite is different to that observed for 

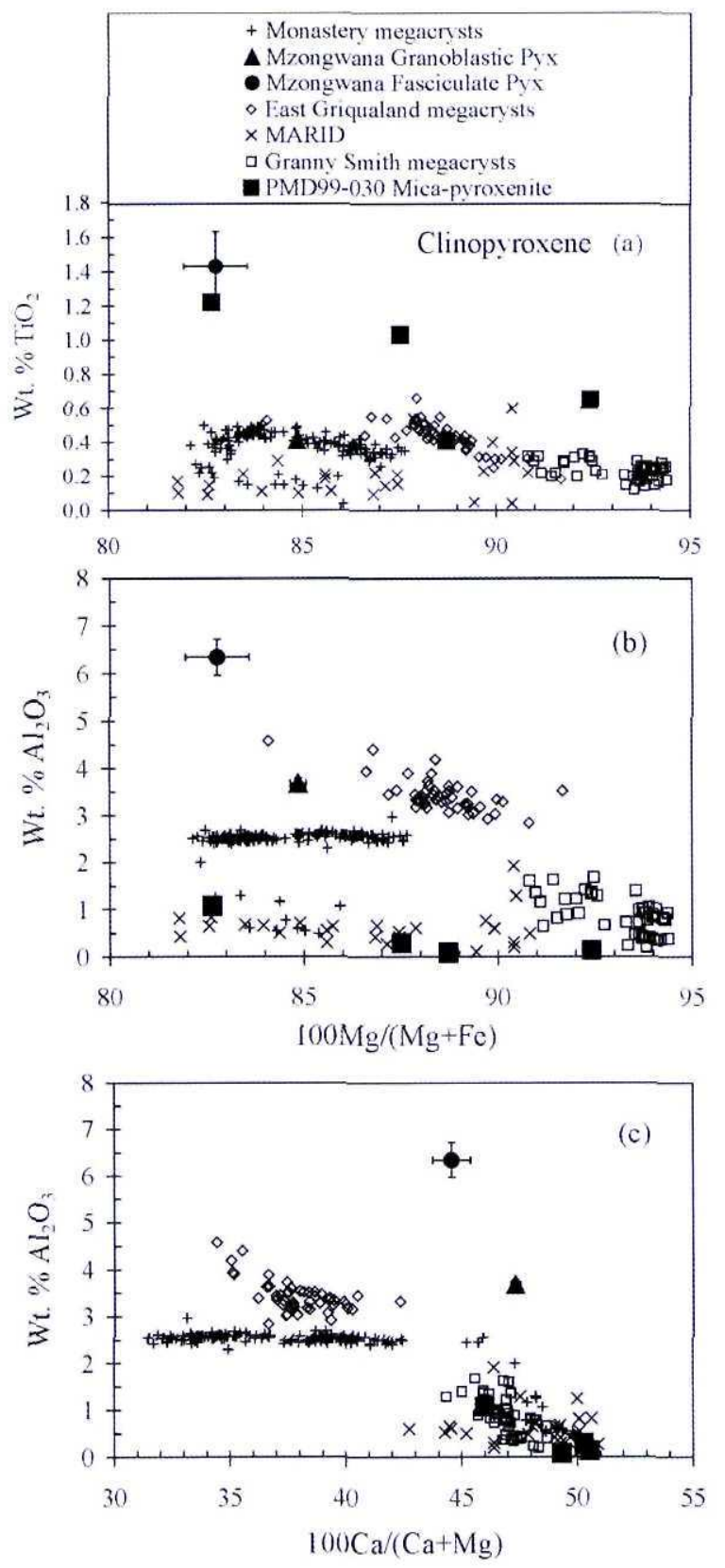

Figure 9. Clinopyroxene compositions, (a) $\mathrm{TiO}_{2} \mathrm{vs}$. $\mathrm{Ng}=$, (b) $\mathrm{Al}_{2} \mathrm{O}_{3}$ vs. $\mathrm{Mg}^{ \pm}$, (c) $\mathrm{Al}_{2} \mathrm{O}_{3}$ vs. Ca\#, P.MD99-032 are analyses of four clinopyroxene grains from this xenolith. Monastery and Mzongwana pyroxenite data as for Figure 7. East Griqualand megacryst data from Bell (unpubl.) and Boyd and Nixon (1980). Granny Smith megacryst data from Boyd et al. (198+a), Hops (1989) and Bell (unpublished data), MARID data from Dawson and Smith (1977), Waters (1986), Konzett et al. (2000) megacrysts at Gansfontein and also to the abundances in typical peridotite xenoliths. No garnet is observed in the Gansfontein megacryst suite, whereas the abundance of orthopyroxene and relative paucity of olivine in the pyroxenite suite xenoliths is opposite to the relative abundances in peridotite and the Gansfontein megacrysts. Trace amounts of olivine in the pyroxenitic rim of PMD99-057 and in PMD99-048, -056 and -099 may be relics of reaction, preserved in the pyroxenite reaction zone between a fluid and olivine-dominated lithologies. Significantly, the pyroxenitic vein in peridotite also contains lamellar orthopyroxene-ilmenite intergrowths, though these are not as well developed as seen in typical megacryst suites such as those of the Monastery. Lesotho and Frank Smith kimberlites (Nixon and Boyd, 1973: Boyd, 1974: Gurney et al., 1979) and have not been observed among the Gansfontein megacrysts.

\section{Summary and significance of mineral compositions}

Minerals occurring in the pyroxenite suite xenoliths generally have $\mathrm{Mg}$ for ilmenite and orthopyroxene that overlap those of megacrysts from Gansfontein. Phlogopite has lower $\mathrm{Mg} \neq$ than a Gansfontein phlogopite megacryst, although only a single megacryst is available for comparison. The samples for which there is visual petrographic evidence of peridotite interaction have compositions that are different from the megacrysts in terms of $\mathrm{Mg} \neq$ and $\mathrm{Cr}$, lying at compositions intermediate to peridotite. The ilmenites from these rocks have lower $\mathrm{Fe}^{3+}$ contents. Low $\mathrm{Fe}^{3+} / \mathrm{Fe}$ was also noted for BD2027 (Rawlinson and Dawson, 1979). Together, these features are strong evidence for interaction of the magma with peridotite.

The chemical trends for orthopyroxene, phlogopite, ilmenite and garnet in the pyroxenites all suggest that these minerals were formed from a melt that was similar to that which precipitated the Cr-poor megacrysts at Gansfontein. This melt was more Fe-rich than the megacryst magma at other localities in southern Africa (Doyle. 1999; Bell and Moore 2004, Bell, unpublished data), including the relatively Fe-rich megacryst suite from the Monastery kimberlite (Gurney et al.. 1979). Garnets in the fine-grained pyroxenite suite partially overlap the Monastery megacrysts in terms of Mg-Fe-Ti relationships, indicating in some cases an equilibration with Monastery-like megacryst compositions for these components. These particular megacryst compositions are those observed to be in equilibrium with ilmenite. However, the lower and variable $\mathrm{Ca}$ contents indicate the lack of equilibration of garnet with orthopyroxene and clinopyroxene that normally should produce constant, buffered Ca contents in $\mathrm{Cr}$-poor megacryst suites.

In these fine-grained xenoliths, the chemical disequilibrium implied by the compositional heterogeneity occurs on very small spatial scales, indicating crystallization shortly before eruption of the 


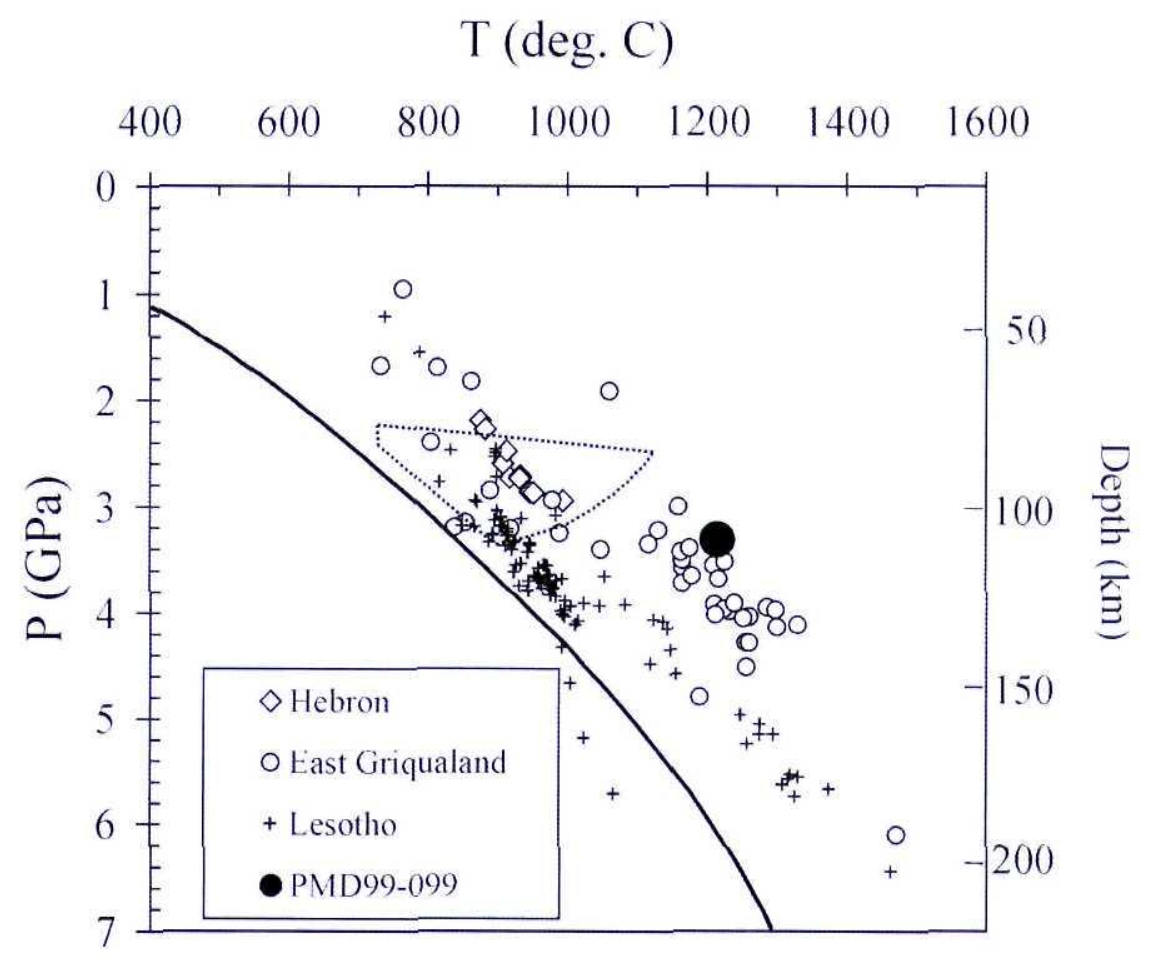

Figure 10. Pressure-temperature diagram indicating conditions of origin of garnet-bearing fine grained pyroxenite sample PMD99-099). For comparison, the pressures and temperatures of peridotite xenoliths from East Griqualand kimberlites (Boyd and Nixon, 1979), the Hebron (Hartebeestfontein) kimberlite (similar to Gansfontein. located $50 \mathrm{~km}$ to the north) (Robey, 1981; F.R. Boyd, unpublished data) and various Lesotho kimberlites are plotted for comparison. All P-T data have been calculated using the $\mathrm{T}_{\text {Ha }}$ (Harley, 1984) thermometer in combination with the $\mathrm{P}_{\mathrm{BKX}}$ (Brey and Köhler, 1990) geobarometer. Solid reference line is a model conductive geotherm calculated for a $40 \mathrm{~m}_{\mathrm{W}} \mathrm{m}^{2}$ surface heat flow (Pollack and Chapman, 1977). Dashed outline field are P-T conditions of origin inferred for rapidly crystallized pyroxenite xenoliths from Mzongwana (Boyd et al.198+h).

kimberlite, as suggested by Boyd et al. (1984h) for the Mzongwana suite. The greatest degree of relative compositional heterogeneity occurs for $\mathrm{Al}$ in orthopyroxene, reflecting presumably the low diffusivity of Al in pyroxene (Sautter and Harte, 1990). Occurrence of recrystallised olivine neoblasts with Fe-rich ( Fo85) compositions in two peridotite xenoliths also indicates that the Fe-enrichment in these samples occurred close to the time of eruption, before significant diffusion into larger, unrecrystallized olivines occurred. In the case of the veined sample, this may indicate that deformation accompanied vein formation, with infiltration of Fe-rich liquid from the vein into the peridotite matrix.

\section{Bulk compositions of fine-grained pyroxenites}

The presence of megacryst-like mineral compositions, the vein-like habit of one sample, the internal layering, presence of occasional idioblastic grains and the presence of high temperatures are features that could indicate an igneous origin for these xenoliths. In addition the fine grained nature of these samples, with their sometimes radiating arrangement of orthopyroxene crystals that recall quench textures, suggest the possibility of a rapidly-crystallized magma. In order to examine this possibility we computed approximate bulk compositions by combining the mineral compositions with our estimates of their modal abundances. The results are given in Table 3, along with analyses of similar fine grained pyroxenite suite nodules from Mzongwana (Boyd et al., 1984h) and Weltevreden (Rawlinson and Dawson. 1979).

Two compositional features of the pyroxenite xenoliths preclude them from being silicate melts crystallized in a closed system: their extremely low $\mathrm{CaO}$ contents $(<1$ weight $\% \mathrm{CaO})$ and their abnormally high $\mathrm{TiO}_{2}$ contents (10-12 weight $\left.\% \mathrm{TiO}_{2}\right)$. Even if these features are exaggerated by incorrect modal estimates, it is clear that the compositions are most unusual. We suggest, instead, that these xenoliths either represent cumulates (where a residual liquid fraction has escaped). or they are the reaction products of melt with solid mantle (with or without the loss of a residual liquid fraction). One possibility is that a highly fluid, residual 
Table 3. Whole rock compositions.

\begin{tabular}{|c|c|c|c|c|c|c|}
\hline $\begin{array}{l}\text { Sample } \\
\text { Type } \\
\text { Locality }\end{array}$ & $\begin{array}{c}\text { PMD99-048 } \\
\text { fgd } \\
\text { Gansfontein }\end{array}$ & $\begin{array}{c}\text { PMD99-099 } \\
\text { fgd } \\
\text { Gansfontein }\end{array}$ & $\begin{array}{l}\text { PMD99-030 } \\
\text { Mica pyx } \\
\text { Gansfontein }\end{array}$ & $\begin{array}{c}\text { PHN3087A } \\
\text { phl-kaers-gar-ilm } \\
\text { Mzongwana }\end{array}$ & $\begin{array}{c}\text { PHN3088 } \\
\text { pyroxenites } \\
\text { East Griqualand }\end{array}$ & $\begin{array}{c}\text { BD2027 } \\
\text { “quench" pyx-ilm } \\
\text { Weltevreden }\end{array}$ \\
\hline $\mathrm{SiO} 2$ & 38.9 & $3+.7$ & +1.5 & 36.4 & 37.4 & 37.98 \\
\hline $\mathrm{TiO}_{2}$ & 10.2 & 12.3 & 5.36 & 10.7 & $7.0-1$ & 12.77 \\
\hline $\mathrm{Al} 2 \mathrm{O} 3$ & 0.17 & 9.40 & 6.44 & 7.49 & 10.1 & 2.01 \\
\hline $\mathrm{Cr} 2 \mathrm{O} 3$ & 0.0 .3 & 0.07 & 0.18 & $0.0^{-}$ & 0.16 & $0.2+$ \\
\hline $\mathrm{F} \cdot \mathrm{O}^{*}$ & 16.1 & 20.1 & 6.96 & $1+.1$ & 13.1 & 14.6 \\
\hline $\mathrm{MnO}$ & 0.12 & 0.18 & 0.08 & 0.25 & $0.2^{-7}$ & 0.16 \\
\hline $\mathrm{MgO}$ & 21.5 & 19.4 & 18.2 & 21.4 & 19.6 & 25.19 \\
\hline $\mathrm{CaO}$ & 0.45 & (0.89) & 11.2 & 5.02 & 6.15 & 2.27 \\
\hline $\mathrm{Na} 2 \mathrm{O}$ & 0.25 & 0.10 & 0.48 & $0 .+2$ & (1).36 & $0 .+3$ \\
\hline $\mathrm{k} 2 \mathrm{O}$ & 3.57 & $1.4^{7}$ & +.37 & 0.48 & 0.50 & 1.32 \\
\hline $\mathrm{Mg}=$ & $70 .+2$ & 63.25 & 82.30 & $7+.5$ & 71.2 & 75.5 \\
\hline
\end{tabular}

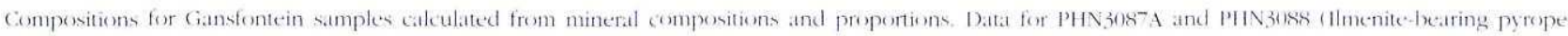
pyroxenites with primary kitersutite and phlogopite) by XRF from Boyd et al. (1984t). Data for B1) 202- from Rawlinson and 1)awson (19)-9). All Fe expressed as $\mathrm{FeO}$, fgd $=$ fine grained discrete pyroxente, mica-pyx = mica pyroxenite

carbonate fraction has escaped from the system. It is rather difficult to imagine how a highly differentiated. incompatible element-rich magma probably related to kimberlite could not be very rich in carbonate, yet there is only minor evidence for its presence in these assemblages. In this context, and given the low affinity of high field strength elements for carbonatitic liquids, it is also difficult to envisage how a carbonate-rich magma could crystallize to an assemblage so rich in Ti, even if a substantial portion of it escaped.

In contrast. the mica pyroxenite xenolith has a bulk composition that is within a reasonable range for a silica undersaturated, ultrapotassic silicate melt. In addition, the bulk $\mathrm{Mg}$ \# is close to that expected for equilibrium with off-craton mantle periclotite ( Fo91). Thus the mica-clinopyroxenite xenolith cannot represent the magma that precipitated the Cr-poor megacrysts, or gave rise to the fine-grained pyroxenite xenoliths, as it is too Mg-rich. It could. however, be derived from such a magma by subsequent equilibration with periclotitic mantle, thus explaining its higher $\mathrm{Cr}$ content and low $\mathrm{Fe}^{3+}$. It could have differentiated to form a magma parental to the megacrysts, although the solid phases that record such an evolution are not in evidence, so that we consider this possibility less likely. The similarity of the mica pyroxenite mineral assemblage and of the pyroxene composition to those in MARID xenoliths is taken as evidence for a similar evolutionary path for these xenolith types. However, the more Ti-rich mineral compositions in the mica-clinopyroxenite suggest that its original compositions may have been different, and that it has an origin in the highly evolved megacryst magma that appears to be a unique feature of the mantle beneath Gansfontein at this time. This is supported by the occurrence of zircon in this xenolith a relatively rare occurrence in MARID xenoliths elsewhere.

\section{Implications of bybrid pyroxenite xenoliths for megacryst-forming processes}

The compositional similarity of pyroxenite-suite minerals to megacrysts indicates the involvement of a magma compositionally similar to that which precipitated the Gansfontein megacrysts. The calculated bulk compositions of the pyroxenite xenoliths and, by implication, the pyroxenite hybrid vein in peridotite, are not compatible with known or plausible igneous liquid compositions. Thus, it is probable that the fine grained textures are not formed by quenching of a liquid (unless significant quantities of liquid escaped from the system), and that the resemblance to experimental and natural magmatic quench products is coincidental. Lack of chemical equilibrium at high temperature is nevertheless unambiguous in implying relatively short timescales in the formation of these rocks.

Petrographic oloservations suggest that the fine grained textures in the pyroxenite xenoliths may result from reaction of magma with solid mantle peridotite. This peridotite may include dunite formed in previous megacryst-forming events (sample PMD99-057). The mineral phases of the cliscrete pyroxenites and the vein in the periclotite sample are the same, but their chemical signatures are somewhat different due partial equilibration with peridotite. However, the compositions, even in this thin vein, are still much closer to the magmatic products than to the peridotitic wall rock, suggesting that if these rocks are reaction products, they are overwhelmingly dominated by the magma and therefore imply high magma to rock ratios. This would suggest that the pyroxenite xenoliths may represent the loci of percolative magmatic flux through subcontinental mantle. The macroscopic layering may represent the reaction fronts that result from successive episodic pulses of magma through the system, and the occasional overgrowths and unusual zoning patterns seen in 
orthopyroxene and garnet crystals, respectively, reflect the compositional complexity of these events. The close proximity to megacrystalline olivine (PMD99-057) and ilmenite (PMD99-099, BD2027) is of particular interest in this regard, and may provide clues as to megacryst forming processes. One possibility is that this fine grained rock represents grain boundary infiltration and metasomatic conversion of the aureole around a locus of megacryst magma migration such as the coarse grained vein in BD2027. While the graphic pyroxene-ilmenite intergrowths represent cotectic crystallization (Wyatt, 1977; Rawlinson and Dawson, 1979), it is apparent that this crystallization may occur during reaction between melt and solid peridotite.

An unexplained observation is the uniformly high orthopyroxene content of these xenoliths wherever they have been found thus far. This high proportion is unexpected for the solidification or reaction products of a highly silica-undersaturated melt and is at odds with the proportions of olivine to orthopyroxene seen in what are regarded as the true magmatic products, namely the Gansfontein megacrysts themselves. One possibility is that the high $\mathrm{Ti}$ content of the magma results in a reaction of the following type:

$(\mathrm{Mg}, \mathrm{Fe})_{2} \mathrm{SiO}_{4}+\mathrm{TiO}_{2}=(\mathrm{MgFe}) \mathrm{TiO}_{3}+(\mathrm{MgFe}) \mathrm{SiO}_{3}$ olivine liquid ilmenite orthopyroxene

At Monastery, the onset of pyroxene-ilmenite intergrowths coincides approximately with the disappearance of olivine from the megacryst fractionation sequence (Gurney et al., 1979; Moore 1986). This observation supports the proposed reaction relationship between titaniferous megacryst magmas and magnesian mantle olivine. We suggest that the unusual textures of the lamellar pyroxene-ilmenite intergrowths could be linked to growth under conditions of this reaction relationship and draw attention to their occurrence in the pyroxenite vein in peridotite (sample PMD99-078). With increased evolution of the megacryst magmas, this reaction relationship would be required to cease, because the more Fe rich. Ni-poor olivines, such as those coexisting with zircon, occur in stable coexistence with ilmenite.

In a hybrid, melt-dominated system, mineral assemblages are dictated by liquid phase relations, although the mineral proportions and their compositions will reflect those of the bulk system. Therefore, megacryst minerals are expected to precipitate, but in proportions different to those normally observed in megacryst suites. We therefore propose that the pyroxenite xenoliths record the interaction of megacryst magmas with peridotite at relatively high integrated fluid/rock ratios, such that compositional features of the magma prevail, but complete conversion to liquidus proportions of minerals has not yet occurred. In the case of sample PMD99-099, for example, garnet (which is absent in the megacryst suite at Gansfontein) crystallizes because in interacting with peridotite, the bulk composition is adjusted so that the garnet phase volume is intersected, as it would be for more primitive megacryst magmas. A similar situation arises for the orthopyroxene-ilmenite intergrowths, which normally occur at compositions less evolved than those found in the Gansfontein megacryst suite. However, the interaction with peridotite shifts liquid compositions to mimic a more primitive melt composition, resulting in the intersection of reactions characteristic of less evolved megacryst magmas.

The pyroxenites, in preserving a snapshot of the process of invasion of megacryst magma into peridotite, presumably represent processes at the margin of the megacryst-forming event. However, it is an interesting question as to whether these incompletely equilibrated assemblages also represent a time slice during the conversion of mantle into a megacryst-bearing zone by the infiltration and metasomatic action of a melt. In sample PMD99-099, megacryst-like garnet grows by the interaction of Fe-rich megacryst magma with peridotite. It is not clear what the equilibrium final assemblage for this particular mix of magma and peridotite is, or how it might change with additional input of melt. However, in the model explored here, both garnet and orthopyroxene with approximately megacryst like compositions can be produced by the reaction of megacryst magma with peridotite. This observation may have significant implications for the petrologic models of megacryst compositional evolution, namely that megacrysts can be formed by the metasomatic conversion of perictotite by melt at high melt/rock ratios, such that compositional features of peridotite are by and large erased, but that the megacryst phase assemblage is dictated by details of the reaction between the two components. Megacryst-forming processes have in the past been considered largely in terms of magmatic evolution such as might be expected in magma chambers or plating out of crystals on the walls of veins or other conduits. We envisage that megacryst formation may involve more solid state reaction than generally recognized.

Finally, the textures and compositional heterogeneity that argue strongly for the existence of a megacryst magma at the time of kimberlite eruption make it rather likely that the two events are intimately related. Kimberlites are far from liquids, containing a great deal of solid mantle material, but the liquid component in them may derive from this megacryst magma. Reaction of megacryst magma with peridotite to produce high- $\mathrm{Mg} \neq$ liquids that are highly enriched in incompatible elements, as proposed for the origin of the Gansfontein mica-clinopyroxenite, can account for many geochemical features of kimberlites and various metasomatic fluids (Jones, 1987; Harte et al., 1993).

\section{Conclusions}

Fine grained xenoliths dominated by orthopyroxene, phlogopite and ilmenite have Fe-rich mineral 
compositions that are similar to those of megacrysts from Gansfontein, but differ in several significant respects. It is proposed that they formed by the interaction of megacryst magma with solid mantle in the form of peridotite, and previously formed megacryst veins or aggregates. The mineral textures, proportions and compositions observed in these fine grained pyroxenites provide evidence for processes of melt-solid reaction in the mantle and suggest that these may be important in generation of the Cr-poor megacryst suite in kimberlites.

\section{Acknowledgments}

We are grateful to Jock Robey of De Beers and Michele Francis for assistance in the field and thank Phil Janney for sharing his unpublished analyses of Gansfontein peridotites. We gratefully acknowledge the support of De Beers for mantle and kimberlite studies at LCT. PMD was supported by a South African government NRF honours bursary. We are grateful to Mr. J. Potgieter of Leeukloof for access to the kimberlite on his property and for his support and interest in the project. Manuscript reviews by Steve Shirey, Deon De Bruin and editorial assistance from Lew Ashwal are appreciated.

\section{References}

Bell, D. R. and Morore, R. O. $(200+)$. Deep chemical structure of the southern African mantle from kimberlite megacrysts. south African lonmal of Geoleger: 107. 59-80)

Bell, D. R. Schmitz. M. 1). Janney, P. E. (2003). Merozose thermal evolution of the southem African mantle lithosphere. Lithos, 71, 273-28-.

Boyd, F. R. (19-7). Liltramafic nodules from the Frank smith kimberlite pipe Carnegie Institution of. Washington learbook. 73. 285-294.

Boyd, F. R. Dawson, J. B., Snith, J. 1. (198ta). Granny smith diopside megacrysts from the kimberlites of the kimberley area and Jagersfontein, South Africa. Geochimica of Cosmochimica Acta, 48, 381-384.

Besd, F. R. and Vixon, P. H. (197-3). Origin of the ilmenite-silicate nodules in kimberlites from leosthe and south Africa. 14. P. H. Nixen PH (Feliker) Lesotho Kinberlites. Lesolbo National Detelopment Corforation. Maseru. $25+-20 \%$

Boyd, F. R and Nixon, P. H. (1975), Origins of the ultramafic nexdules from some kimberlites of nothern Lesotho and the Nonastery Mine, South Africa. Physics and Chemistry of the Earth. 9. $431-454$.

Boyd. F. R. and Nixon, P. H. (1980). Discrete nodules from the kimberlites of East Griqualand, southem Africat. Carnegie Institution of IVasbington rearbook, $79.290-302$

Boyd, F. R., Vixon. P. H. and Bector. V. Z. (198+b), Rapidly orystallized garnet proxenite xemoliths pussible related (s) discrete nodules. Contributions to . Hineralogit and Petrologi: 86, 119-1,30.

Bres, G. P. and köhler, T. $(1990)$. Geothermobaromery in four phase therzolites If. New thermobarometers and practical assessment of existing thermobarometers formal of Petrologr: 31. 1353-1378.

Burgess, S. R. and Harte, B. (1909). Tracing lithosphere evolution through the analysis of heterogeneous G9) G10 garnets in peridotite xenoliths, I: major element chemistry. In. I. I. Gurner, I.L., Gurney. M. D. Pascox and S. H. Richardson (Fditors). The J.B. Dawson Volume, Proceedings of the 7th International kimberlite Conference, Red Roof Design, Cape Toun. South . Africa, $60-80$

1)awson, I. B. and smith, J. V. (1977), The MARII) (mica-amplitole-rutileilmenite-diopside) suite of xenoliths in kimberlite Geochimica et Cosmochimica Acta, 41, 309-323

De Bruin. D), (1993). The megacryst suite from the Schuller kimberlite, South Africa, Bulletin of the Geological Surver of South Afitica, 114, $112 \mathrm{pp}$. Doyle, P. M. (1909). A petrologic and gershemical study of the megatryst suite and related nodules from the Gansfontein kimberlite. RSA.
Inpublished B.Sc llonous thesis. Iniversity of Cape Toun, South Africa. $8+\mathrm{pp}+$ appendices

Fggler, D. H., Mecallum, M.F, and smith, C.B. (19-9) Megacryst assemblages in kimberlite from nosthern Colorado and southern Wyoming: petrology. geothemometry-harometry, and areal distribution. In F, R. Boyd and $\mathrm{H}$. O. A Neyer (Fditors) The mantle sample: inclusions in kimberlites and other volcanics. American Geophysical Lnom. Washington, D.C., L.S.A. 213-226.

Griffin, IV. L.. O'Reilly, S. Y., Natapoy, L. M. and Ryan, C. G. (2003). The evolution of the lithospheric mantle beneath the Kalahari Craton and its margins, lathos, $71,215-2+1$

Gurney. J. I., Fesq. H. W. and Kable. E. J. D. (1973). Clinopyroxene-ilmenite intergrowths from kimberlite; a re-appraisal. In: P. H. Nixon (Editor) lesotho kimberlites. Lesotho Vational Detelopment Corporation. Maseru. $238-253$.

Gurney, J. J. and Harte, B. (1980) Chemical variations in upper mantle nodules from southern African kimberlites. Pbilosophical Transactions of the Rescal soctety of London, A297. 273-293

Gurney, I. 1. Jakoh. R. E.. Dawson. I. B. (19-9) Megaterysts from the Vonastery kimberlite, South Africa. In. F. R. Boyd and H. O. A. Meyer (Fditors) The mantle sample: inclusions in kimberlites and other volcanics. American Geophistical linion. Washington. D.C. L.S.A., 227-243.

H:arley. S. 1. (1984). An experimental study of the partitioning of Fe and $\mathrm{Mg}$ between garnet and orthopyroxene. Contributions to vineralogy and Petroluge: 86, 359-373.

Harte, B. Hunter. R. H. and Kinny. P. D. (1993), Melt geometry, movement and crystallization, in relation to mantle dykes, veins and metasomatism. Philsoptrical Transactions of the Royal Soctety of London, A342, 1-21.

Hops, 1. 1. 1989y Some aspects of the geochemistry of high-temperate peridotites and megacrysts from the Jagersfontein kimberlite pipe. South Africa. Inpublished Ph.D. Whesis. Uniersity of Cape Toun. South Africa. zospp.

Hops. 1. 1. Gurney. J. 1.. Harte, B. and Winterhurn, P. (1989). Megacrysts and high temperature nodules from the Jagersfontein kimberlite pipe In: J. Ross, A. L. Jaques, J. Ferguson, D. H. Green, S. Y. O'Reilly, R. V. Danchin and A. J. A. Janse. (Editors). Kimberlites and Related rocks, Volume 2. Their mantlecrust setting, diamonds and diamond exploration Geological Society of Atastralia special Publication. 14, -759-770.

lakob. W. R. O. (19-7), Geochemical aspects of the megacryst suite from the Nonastery kimberlite pipe. Inpublished us.Sc. thesis. Unicersity of Cape Toun, South Africa. $81 \mathrm{pp}$.

Janney, P. E., Carlson. R.W., Shirey, S, B.. Bell, D, R. and Le Roex, A. P. (1999). Remperature, pressure and Re-Os age systematics of peridotite xenoliths from the off-craton Namacqua- Vatal belt. Western South Africa. Extended Abstracts, 9th Anmual V. .1. Goldschmidt Conference. Abstract $=7268$. LPI Contribution No. 971, Lunar and Planetary Institute. Houston, lSA, (CD) Rom.

Janney, P. E. Cartoon, R W. Shirey \& B. Bell D R and le Rexex. A P. (2001), Re-Os Age and Thermal Structure of Off-Craton Lithospheric Mantle in Western South Africa Los, Ahstracts. AGt Spring . Feoting 2000.

fones. R. A. (1987), Strontium and neodymium isotopic and rare-arth element evidence for the genesis of megacrysts in kimberlites of southern Africa. In: Nixon. P. H. (Editor), Mantle xenoliths, John Wiley and Sons. Chichester, 11.K., $711-727$.

Kelemen. P. B. (1995). Gencration of high-Mg andesites and the continental crust. Contributions to Mineraloger and Petrology: 120, 1-19

Kelemen, P. B., Dick, H. I. B. and Quick, J. E. (1992). Formation of harzhurgite by pervasive melt rock reaction in the upper mantle, Nature, 358, 635-6+1.

Kelemen, P. B., Shimizu, N. and Salters, V. J. M. (1995). Extraction of midocean-ridge basalt from the upwelling mantle by focused flow of melt in dunite channels. Nature. 375, 7,7-753.

Konzutt 1. Armstrong, R. A. and Gunther. D. (2000). Modal metasomatism in the Katapval craton lithosphere: constraints on timing and genesis from 1-Pb zircon dating of metasomatized peridotites and MARID-type xenoliths, Contributions to Bineralogy and Petrology: 139, 704-719.

Moore, R. O. (1986). A study of the kimberlites, diamonds and associated rocks and minerals from the Monastery Mine, South Africa. Unpublistied Ph.D, thesis, Lniversity of Cape Town. South Africa, $35+\mathrm{pp}$.

Moore, R. O.. Griffin, W. I.. Gurney, J. J. Ryan, C. G.. Cousens, D. R., sie, S. 
H. and suter, G. F. (1092). Trace element geeshemistry of ilmenite megactysts from the Nonastery kimberlite, South Africa, Lithos, 29, 1.18.

Neal. C. R. and Davidson. I. P. (1989). An unmetasomatized source for the Nalaitan alnoite (Solomon Islands) : Petrogenesis involving ane refining megacryst fractionation. and assimilation of oceanic lithosphere Gerchimica el cosmochimica Acta. 53. 1975-1990.

Nixon, P. H. and Boyd, F.R. (19-5), The discrete nodule association in kimberlites from Nothern Lesotho, In: P.IL Nixon (Editor), lesotho kimberlites, Lesolbo Natonal Detelopment Corporation, Iasem, 67-75.

Pollack. H, N. and Chapman, D. S. (19-7), On the regional variation of heat How. geothems and lithospheric thickness. Tectonophysics 38, 2-9-296.

Pouchou. J. L. and Pichoir. R. (1991) Quantitative analysis of homogeneous or stratified microsolumes applying the model "PAP", In: K. F. I. Heinrich and D. E. Newbury (Editurs). Flatron prole quantitation. Plenum. Nen Jirk: I.S.A. 31-76

Rawlinson, P. I. and Dawson, 1. B. (19-9), A quench pyroxene-ilmenite xenolith from kimberlite: implications for pyroxene-ilmenite intergroweths. In: F. R. Boyd and H. O. A. Meyer (Fditors). The mantle sample: inclusion. in kimberlites and other volanics. Amorican cieoplystacal thom. Washingtom. 1)... L.S.t. 292-299.

Rickwood. P. C. (1969). The nature and occurrences of non-edegitic ultramafic xenoliths in the kimberlites of southern Africa. Cieological society of South Africa Special Publication. 2. 395-116.

Robey, J. V. (1981). Kimberlites of the Central Cape Province. South Africa Cupublished Ph,D. thesis, Chitersity of Cape Toum, South Afitica, $261 \mathrm{pp} .+$ appendices.

Rogers. A W. (1910), Geological survey of parts of the divisions of Beaufort West, Fraserburg, Victoria West. Sutherland and Laingsburg. Anmual Repent of the Gerdogical Commission of the Cape of Good Hope 15. 9-600

Sautter, V. and Harte, B. (1990). Diffusion gradients in an eclogite xenolith from the Roberts Victor kimberlite. (2) kinetics and implications for petrogenesis. Contributions to Mineralogy and Petrology: 105. 637-649)
Schulac, 1). I. (19)4). (r-poor megacrysts from the Hamilton Branch kimberlite, Fllist County. Kentucky. In: J. Kornprolast (Fiditor) Kimberlites I1. The Mantle and Crust-Mantle Relationships. Detelopments in Petrology: liseties: Amsterdam, the Veflerlands. 11B, 9-108.

schulze, 1).1. (1987), Megacryst from alkalic volcanic rocks, In: P.H. Nixon (Editor). Nantle Xenolith. Jobn wiley and sons, Chichester: $2 . K,+33-152$ smith. 1). (1999). Temperatures and pressures of mineral equilibration in peridotite senoliths: review, discussion, and implications. In Y. Fei, C. M. liertka and B. O.Mysen (Editors). Mantle petrology: fictd observations and high pressure experimentations a tribute to Francis R. (Joe) Boyd. Geochemical Society special Publicution. 6, 171-18s

smith. 1), and Boyd, F, R. (198-). Compositional heterogeneities in a high temperature therzolite nodule and implications for mantle processes. In P.II. Vixon (Fditor). Mantle Xenoliths. Jobn Iriley and soms. Chichester: [. K. $551-5(1)]$.

Wagner. T. P. and Grose. T.L. (1998). Met harzburgite reaction in the petrogenesis of tholeritic magma from kilatea Volcano. Hawaii. Contributions to Dineralogy and Petrologe: 131, 1-12.

Watters, F. G. (198-), A geochemical study of metasomatized peridotite and MARII nodules from doe kimberley pipes, South Africa. Lupublistreal Ph.D.

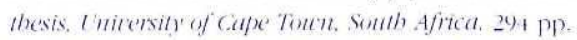

Wyatt. B.A. (19)77), The melting and crystallization behaviour of a natural clinopyroxene-ilmenite intergrowth. Contributions to buneralogy and Petrolege: 61, 1-9)

Wyllic. P. J.. Carroll, M. R., Johnston, A. D., Rutter, M. I., Sekine, T, and Van der Laan, S. R. (1989). Interactions among magnas and rocks in sulduction zone regions: experimental studies from slab to mantle to crust. European Journal of Mincraloge: 1, 165-179.

Editorial handling: M. J. de Wit 
Copyright of South African Journal of Geology is the property of Geological Society of South Africa and its content may not be copied or emailed to multiple sites or posted to a listserv without the copyright holder's express written permission. However, users may print, download, or email articles for individual use. 